\title{
Auditory nerve and interneurone responses to natural sounds in several species of cicadas
}

FRANZ HUBER, DAVID W. WOHLERS and THOMAS E. MOORE* Max Planck Institut für Verhaltensphysiologie, Abtl. Huber, Seewiesen, F.R.G., and * The University of Michigan, Museum of Zoology, Ann Arbor, Michigan, U.S.A.

\begin{abstract}
The calling and courtship songs of 17-year cicadas and of Say's cicadas differ both in the sound frequency spectrum and in temporal pattern. Multiunit recordings with hook electrodes from the whole auditory nerve show that the hearing organs are especially sensitive to transient stimuli occurring in natural sounds. Artificially produced clicks elicit bursts of spikes synchronized among various primary sensory fibres. These fibres respond to natural calling and courtship songs with a specificity dependent on carrier frequency, rhythm and transient content of the sound, following sound pulses (i.e. tymbal actions) up to repetition rates of $200 \mathrm{~Hz}$. An ascending, plurisegmental interneurone was characterized by intracellular recording and simultaneously stained with cobalt. Its main arborization spatially overlaps the anterior part of the sensory auditory neuropile, and the axon was traced as far as the prothoracic ganglion. Direct input from primary auditory fibres was suggested by latency measurements. Intracellular recordings from such neurons in different species show distinct auditory input, with phasic-tonic spike responses to tones. In general, the interneurone response is more species-specific to calling than to courtship songs, and the preferential response to the conspecific calling song is based primarily upon sound frequency content.
\end{abstract}

\section{Introduction}

Cicadas have been used to study sound communication in insects (see Alexander, 1960). In most species only the males produce sounds (Pringle, 1954, 1957; Popov, 1975), while both sexes possess hearing organs (Vogel, 1923; Miche1, 1975; Young \& Hill, 1977).

Sound reception at the level of the auditory nerve has been previously investigated in several species of cicadas, showing the response to the temporal structure of the song (Pringle, 1954), to pure tones and to clicks (Enger et

Correspondence: Professor Dr F. Huber, Max Planck Institut für Verhaltensphysiologie, D 8131 Seewiesen, F.R.G. al., 1969). Threshold curves show an optimal auditory sensitivity correlated to the sound spectrum of the conspecific song (Katsuki, 1960; Katsuki \& Suga, 1960; Enger et al., 1969; Simmons et al., 1971; Young \& Hill, 1977).

The course of the auditory nerve and its central projections have been studied by Wohlers et al. (1979); this anatomical work provided a background for the physiological investigations reported in this paper, where responses to natural calling and courtship songs were recorded either extracellularly from the whole auditory nerve or intracellularly from an identified ascending interneurone. 


\section{Materials and Methods}

Adult 17-year cicadas, Magicicada septendecim (L.), M.cassini (Fisher), M.septendecula (Alexander \& Moore), were collected in June 1978 in Botecourt Co., Virginia, and Say's cicadas, Okanagana rimosa (Say), with a life cycle of 8-10 years, in July in Montmorency Co., Michigan. All specimens were caged on potted cistena plum shrubs (Prunus sp.) where they could feed, and where females could oviposit. The cicadas were transported to the laboratory in Ann Arbor.

For electrophysiological studies the animals, with the legs and wings removed, were mounted upside down on a rigid platform. The nervous system was then exposed from the prothoracic ganglion caudal to the area of the sternal canal (Vasvary, 1966). A silver platform serving as an indifferent electrode was positioned under the fused metathoracicabdominal ganglionic complex for support. Fielden's ringer (Fielden, 1960) replaced the haemoly mph.

Auditory nerve recordings (Fig. 1, lower left) were carried out with hook electrodes $(40-\mu \mathrm{m}$ steel wires), placed approximately $8 \mathrm{~mm}$ from the hearing organ. The nerve was gently lifted out of the saline solution and cut near the ganglion to eliminate efferent activity caused by motoneurones (Wohlers et al., 1979). Vaseline was then placed on the exposed nerve to prevent dehydration.

Auditory interneurones were located in the metathoracic ganglion and penetrated intracellularly (Fig. 1, CE). 3-M potassium-acetatefilled microelectrodes (30-50 megohms) were used for prolonged studies of responses (more than $30 \mathrm{~min}$ ), while $30 \%$ cobalt-nitrate-filled electrodes served simultaneously to record and

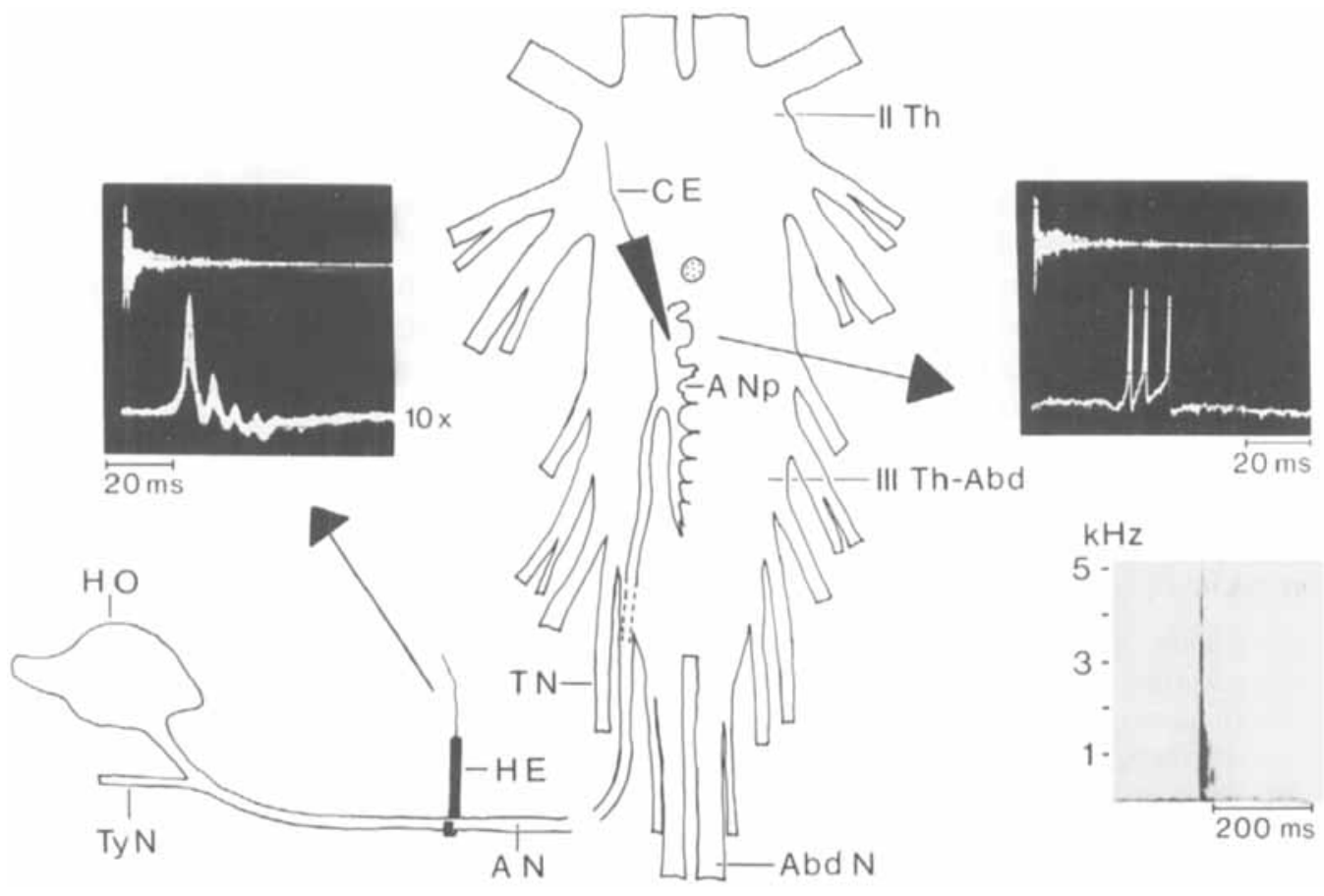

FIG. 1. Schematic drawing of the mesothoracic (II Th), metathoracic (III Th) and abdominal (-Abd) ganglionic complex of a male 17-year cicada (middle) showing the two recording sites: extracellular hook electrode (HE) recording from the cut auditory nerve (AN), and intracellular recording (CE) from an interneurone in the anterior region of the auditory neuropile (ANp) within the metathoracic ganglion. Abd N, abdominal nerve; HO, hearing organ, TyN, nerve branch to tymbal muscle; TN, tensor nerve. Insets. Upper left - auditory nerve responses (ten superimposed sweeps, lower trace) to 'click' sounds produced by human mouth (upper trace). Upper right - interneurone response (lower trace) recorded intracellularly to a single 'click' sound (upper trace). Lower right - sound spectrogram of such a 'click'. 
stain the neurones. Details of the methods were similar to those described by Wohlers \& Huber (1978). Stained cells were intensified using the Timm's technique, modified by Bacon \& Altman (1977). Treated ganglia were embedded in soft Araldite, and thick sectioned $(40 \mu \mathrm{m})$. Reconstructions were made on a Wild M20 microscope equipped with a drawing tube.

Acoustic stimuli were of three types. Tick sounds ('clicks'), produced by the human mouth, of short duration ( $<20 \mathrm{~ms}$; exponential decay) and covering frequencies from a few $\mathrm{Hz}$ to more than $6 \mathrm{kHz}$ (Fig. 1, audiospectrogram, lower right). Pure tones $(500 \mathrm{~Hz}$ to $10 \mathrm{kHz}$ ), delivered through a Nagra (Kudelski) Model DH amplifier and speaker located $130 \mathrm{~cm}$ from the hearing organs. Natural songs, presented from a magnetic tape (15 i.p.s) using a Magnecord tape recorder (Model PT 63-A2HZ) and amplifier (Model PT 63-J) with speaker also located $130 \mathrm{~cm}$ from the hearing organs.

Data were stored on a Racal Store 4D tape recorder and analysed from Polaroid pictures and oscilloscope films. Audiospectrograms (sonograms) of the various acoustical stimuli were made using a Kay Vibralyzer $7030 \mathrm{~A}$ Sound Spectrum Analyser (range $1-16 \mathrm{kHz}$ ). A General Radio Company Sound and Vibration Analyzer Type 1564A was used to measure the sound intensities in $\mathrm{dB}$ SPL $\left(0 \mathrm{~dB}=2 \times 10^{-5} \mathrm{Newton} / \mathrm{m}^{2}\right)$ at the location of the hearing organ. No attempt was made to differentiate between ipsi- and contralateral sound intensities.

\section{Results}

\section{Biological aspects}

The three species of 17-year cicadas live sympatrically and are intermingled individually. Within the brood we observed in Botecourt Co., Virginia, individuals of the same and of different species often fed and oviposited only 10-15 cm apart (see Dybas \& Davis, 1962), though according to Alexander \& Moore (1962) there is no sign of cross-copulation and hybridization. The three species can be distinguished through differences in acoustical behaviour, and their songs are among the most specialized of North American cicadas.
The males produce three types of sound signals (Moore \& Alexander, 1956; Alexander \& Moore, 1958): a calling song, consisting of buzzes and/or ticks emitted either individually or in chorus, is responsible for activating and assembling both males and females; a courtship song ('sound') also consisting of buzzes and/or ticks and produced by individual males when approaching and contacting other individuals, usually females; a disturbance sound ('squawk') when startled into flight or restrained in any way.

Based on audiographic studies (Alexander \& Moore, 1958) the frequency spectrum and the pulse rate (i.e. rate of tymbal actions), as well as the occurrence of buzzes and ticks varies in characteristic fashion (Table 1). In addition to these differences in temporal pattern and frequency spectra of each song type, there are also differences in the manner of flight and chorusing. After one to several calling phrases, M.septendecim undergoes a bout of flight whereas M.cassini and M.septendecula fly, or at least flip their wings, usually after each phrase (Alexander \& Moore, 1962). In the field, synchronized chorusing and flight in M.cassini need warmth and sunshine. Chorusing usually begins around $13.00-14.00$ hours local time and continues throughout the afternoon (Alexander \& Moore, 1962; Heath, 1967).

Okanagana rimosa is a species with the individuals spaced less densely, but usually within a rather limited area. They often broadly overlap geographically and seasonally with 17-year cicadas. In 1978 in Montmorency Co., Michigan, an area of $3 \times 50 \mathrm{~m}$ was occupied by about 200 individuals, and the next population was several kilometres away. The calling and courtship songs are uniform; they vary in duration (Table 1), and contain nearly equally spaced pulses (paired tymbal actions). Each audiospectrographic pulse of sound (see Fig. 6, 3) is composed of 2-4 sound bursts from $2-4$ tymbal ribs in each tymbal, resulting in a total of 5-8 sound bursts/pulse (per paired action of both tymbals, Fig. 6,1$)$.

\section{Electrophysiological studies}

Extracellular recordings were carried out from the auditory nerve, usually ipsilateral to the sound source. This nerve contains at least 
TABLE 1. Sound parameters from various songs of the three 17-year cicadas (Magicicada) and of Say's cicada (Okanagana rimosa) (after Alexander \& Moore, 1962, in part). In all species mentioned in the table each sound pulse is composed of $2-7$ bursts of sound produced by the inward buckling of $2-7$ sclerous ribs in each tymbal for each muscle contraction.

\begin{tabular}{|c|c|c|c|}
\hline \multirow[t]{2}{*}{ Species* } & \multicolumn{2}{|c|}{ Frequency range $(\mathrm{kHz})$} & \multirow[t]{2}{*}{ Temporal structure (rhythm) } \\
\hline & Carrier & Main sound & \\
\hline \multicolumn{4}{|c|}{ Calling songs } \\
\hline M. sept. & $1-2$ & $1-2$ & $\begin{array}{l}\text { Buzzes (duration } 2-4 \mathrm{~s} \text { ) separated by pauses of } 0.5-2.0 \mathrm{~s} \text {; } \\
\text { buzzes composed of pulses }(120-160 / \mathrm{s} \text { ), each pulse represents } \\
\text { one contraction of a ty mbal muscle and its resulting tymbal } \\
\text { and abdominal vibrations. }\end{array}$ \\
\hline M.cass. & $4-12$ & $4-6$ & $\begin{array}{l}\text { A series of } 12-40 \text { ticks (duration } 10 \mathrm{~ms} \text { ) delivered at } 16- \\
25 / \mathrm{s} \text { followed by a buzz (duration } 1-2 \mathrm{~s} \text { ). Pulse rate within } \\
\text { the buzz } 180-210 / \mathrm{s} \text {. }\end{array}$ \\
\hline M.sptd. & $4-14$ & $\begin{array}{l}4-6 \text { buzzes } \\
6-12 \text { ticks }\end{array}$ & $\begin{array}{l}\text { A series of alternations between buzzes and ticks }(25-35 \\
\text { buzzes and ticks) with steadily increasing intensity and rate, } \\
\text { followed by ticks }(18-24) \text { of rather constant intensity and } \\
\text { rate (no buzzes). Pulse rate within buzzes } 130-150 / \mathrm{s} \text {. }\end{array}$ \\
\hline o.rim. & $6-12$ & $7-11$ & $\begin{array}{l}\text { Continuous-sounding buzz (duration up to } 1 \mathrm{~min} \text { ) composed } \\
\text { of double pulses (duration } 6-8 \mathrm{~ms} \text { ) produced at rate of } \\
70-84 / \mathrm{s} \text {; each double pulse produced by combined close } \\
\text { alternation of both ty mbals. Rather constant intensity. }\end{array}$ \\
\hline \multicolumn{4}{|c|}{ Courtship songs } \\
\hline M. sept. & $1-3$ & $1-2$ & Short buzzes (duration $40 \mathrm{~ms}$ ), rate $5 / \mathrm{s}$. \\
\hline M.cass. & $4-14$ & $5-8$ & $\begin{array}{l}\text { A series of double ticks (durations } 20-25 \text { and } 15-25 \mathrm{~ms} \text { ) } \\
\text { separated by } 20-25 \mathrm{~ms} \text {; rate } 6-7 / \mathrm{s} \text {. }\end{array}$ \\
\hline M.sptd. & $4.5-14$ & $5-9$ & Ticks (duration $80-120 \mathrm{~ms}$ ); rate $3-5 / \mathrm{s}$ \\
\hline O.rim. & $4.5-15$ & $6-12$ & $\begin{array}{l}\text { Temporal structure (rhythm) as calling song, but of shorter } \\
\text { duration (up to } 1 \text { s) and increasing intensity. }\end{array}$ \\
\hline
\end{tabular}

* See Methods for full names.

1300 primary auditory sensory fibres (Michel, 1975; Young, 1975). This large number of axons within a nerve $60 \mu \mathrm{m}$ in diameter greatly complicates unravelling the function of single primary auditory fibres. Intracellular recordings were obtained from interneurones responding to natural sounds, but only those recordings which lasted at least $30 \mathrm{~min}$ were evaluated.

\section{A uditory nerve recordings}

Tick sounds (clicks) were produced by the human mouth at intensities of $70-.80 \mathrm{~dB}$ SPL (Fig. 1, inset, upper left). They covered a frequency range from a few $\mathrm{Hz}$ up to more than $6 \mathrm{kHz}$, with the main sound energy being delivered in the range of $500 \mathrm{~Hz}$ to $2 \mathrm{kHz}$ (Fig. 1, inset, lower right). Clicks elicited bursts of spikes which summed to compound action potentials (Fig. 1, inset, upper left, lower trace). The response most commonly exhibited 3-4 peaks spaced about 5-6 ms apart. The decrease in peak amplitude with time suggests a reduction in the number of actively participating primary auditory fibres with time, and that the response reflects the decreasing amplitude of the signal. All species tested responded similarly. In 17-year cicadas the latency of the response to clicks varied from 18 to $22 \mathrm{~ms}$, while O.rimosa showed latencies of $20-23 \mathrm{~ms}$.

In our set-up, the sound-travel time from the speaker to the hearing organs was $4 \mathrm{~ms}$ (distance $130 \mathrm{~cm}$ ). Given this, a transduction time of $1-2 \mathrm{~ms}$, and the distance of $8 \mathrm{~mm}$ from the hearing organ to the recording site in the auditory nerve, the conduction velo- 
city was calculated as between 0.5 and $0.6 \mathrm{~ms}$. This low velocity agrees with the small diameter of the primary auditory fibres $(<1 \mu \mathrm{m})$.

In the four species tested, the inter-ear distance is $c .1 \mathrm{~cm}$, resulting in a sound-travel time of $30 \mu$ s between the two hearing organs. No time difference was measurable in the auditory nerve responses to clicks when recording from both auditory nerves simultaneously. The compound action potentials of both nerves usually had very similar shapes, showing the same number of peaks in decreasing amplitude with time.

Click sounds also gave rise to interneuronal responses (Fig. 1, inset, upper right) which most commonly contained $3-4$ spikes. The inter-spike intervals are not necessarily equal to the inter-peak intervals of the auditory nerve response.

Pure tones elicited a few compound action potentials (peaks) of decreasing amplitude followed by a more or less sustained low amplitude discharge. Similar 'phasic-.tonic' responses were described by Enger et al. (1969) in a Brazilian cicada. Although our set-up was not calibrated for measuring threshold curves, we could roughly determine the best sound frequency responses and compare them with the optimal auditory sensitivities measured by Simmons et al. (1971), see Table 2. Tone pulses also excited auditory interneurones (Fig. 7,1 ).

Natural sounds were preferred for the study
TABLE 2. Best auditory sensitivity in two 17-year cicadas, stimulated at $85 \mathrm{~dB}$ SPL

\begin{tabular}{lll}
\hline Species & $\begin{array}{l}\text { Optimal sound frequency } \\
(\mathrm{kHz})\end{array}$ \\
\cline { 2 - 3 } & $\begin{array}{l}\text { Simmons } \\
\text { et al. }(1971)\end{array}$ & $\begin{array}{l}\text { Present } \\
\text { observations }\end{array}$ \\
\hline $\begin{array}{l}\text { M.septendecim } \\
\text { M.cassini }\end{array}$ & $1.5-2.5$ & 2 \\
\hline
\end{tabular}

of the specificity of auditory nerve and interneuronal responses. Fig. 2 (1, lower trace) shows compound auditory nerve potentials in response to the playback of the conspecific calling song from M.septendecim. An initial burst of compound action potentials (arrow) is followed by a rather irregular discharge of many primary auditory fibres. The calling song also excited an auditory interneurone (Fig. 2, 2, lower trace). Here the phasic components indicated by grouping of spikes (arrows) are much more pronounced and may reflect fast amplitude modulations in the song.

\section{Specificity of auditory nerve responses}

The comparison of auditory nerve responses to conspecific and allospecific calling songs presented at $80 \mathrm{~dB}$ SPL (Fig. 3) revealed some remarkable differences. M.septendecim showed the highest degree of activation in response to the conspecific calling song (Fig. 3, 1 left),
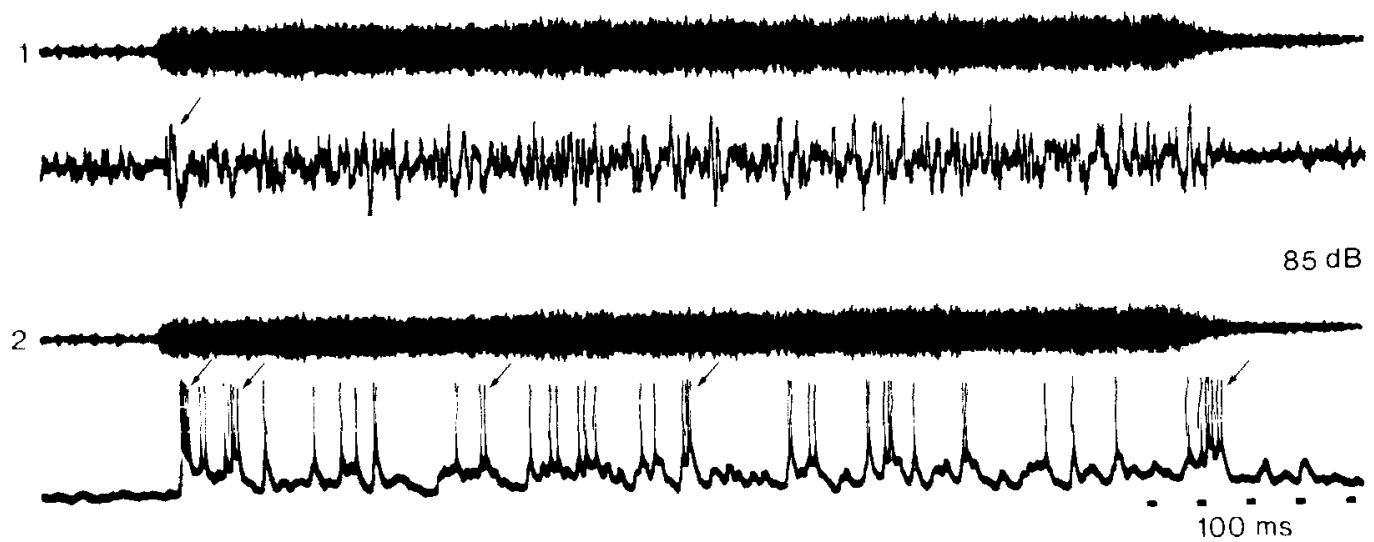

FIG. 2. Oscillograms of auditory nerve (lower trace in 1) and interneurone responses (lower trace in 2) to conspecific calls of M. septendecim (upper traces in 1 and 2) presented at intensities of $85 \mathrm{~dB}$ SPL. Arrows point to bursts of spikes caused by sudden amplitude modulations in the song. 

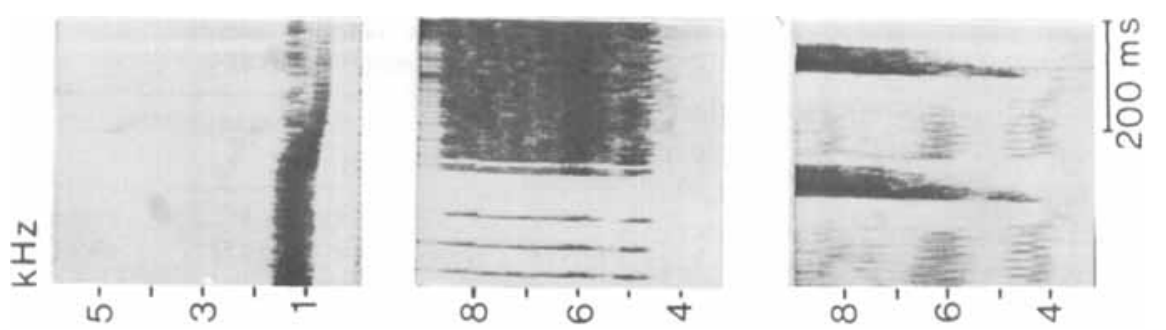

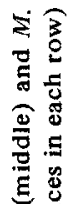
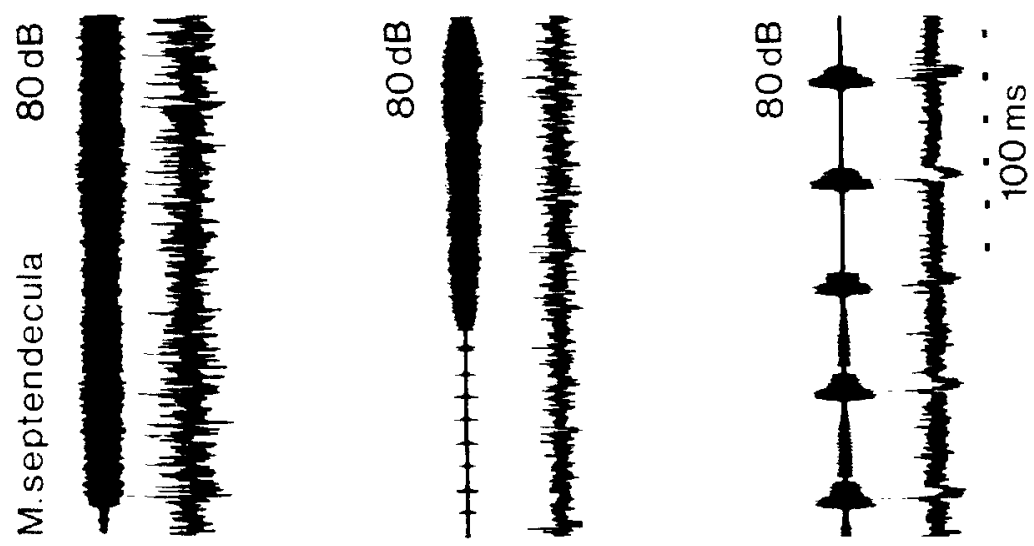

$\tilde{\Sigma}$

. 8

ㅎํㅇ

正

象

등

ชั้

के

要,

造要

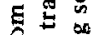

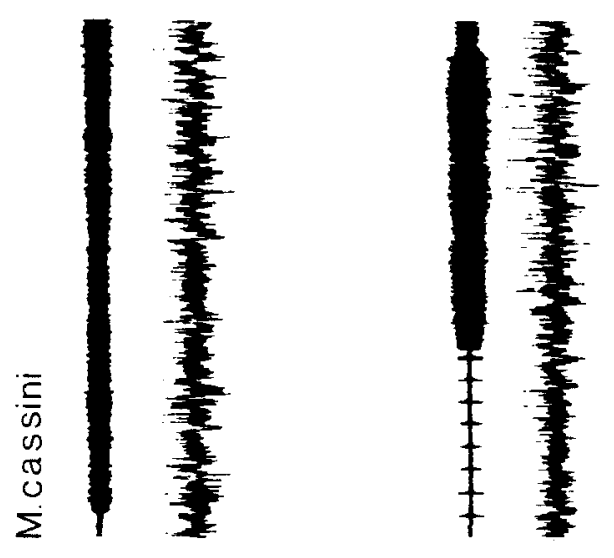

1 告
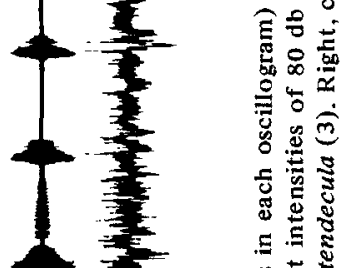

4 告

1 는

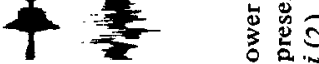
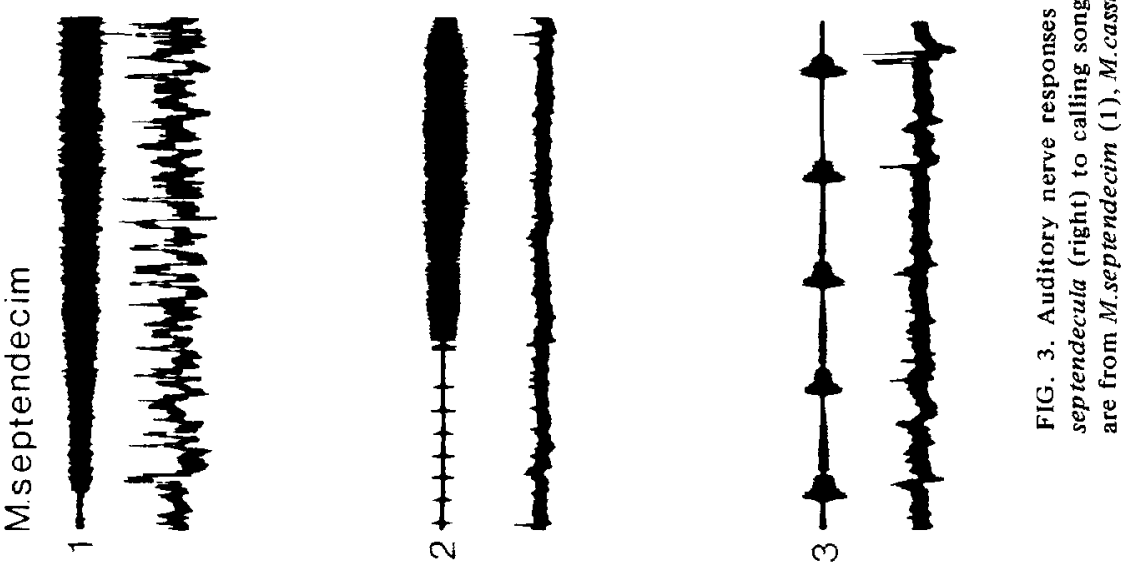

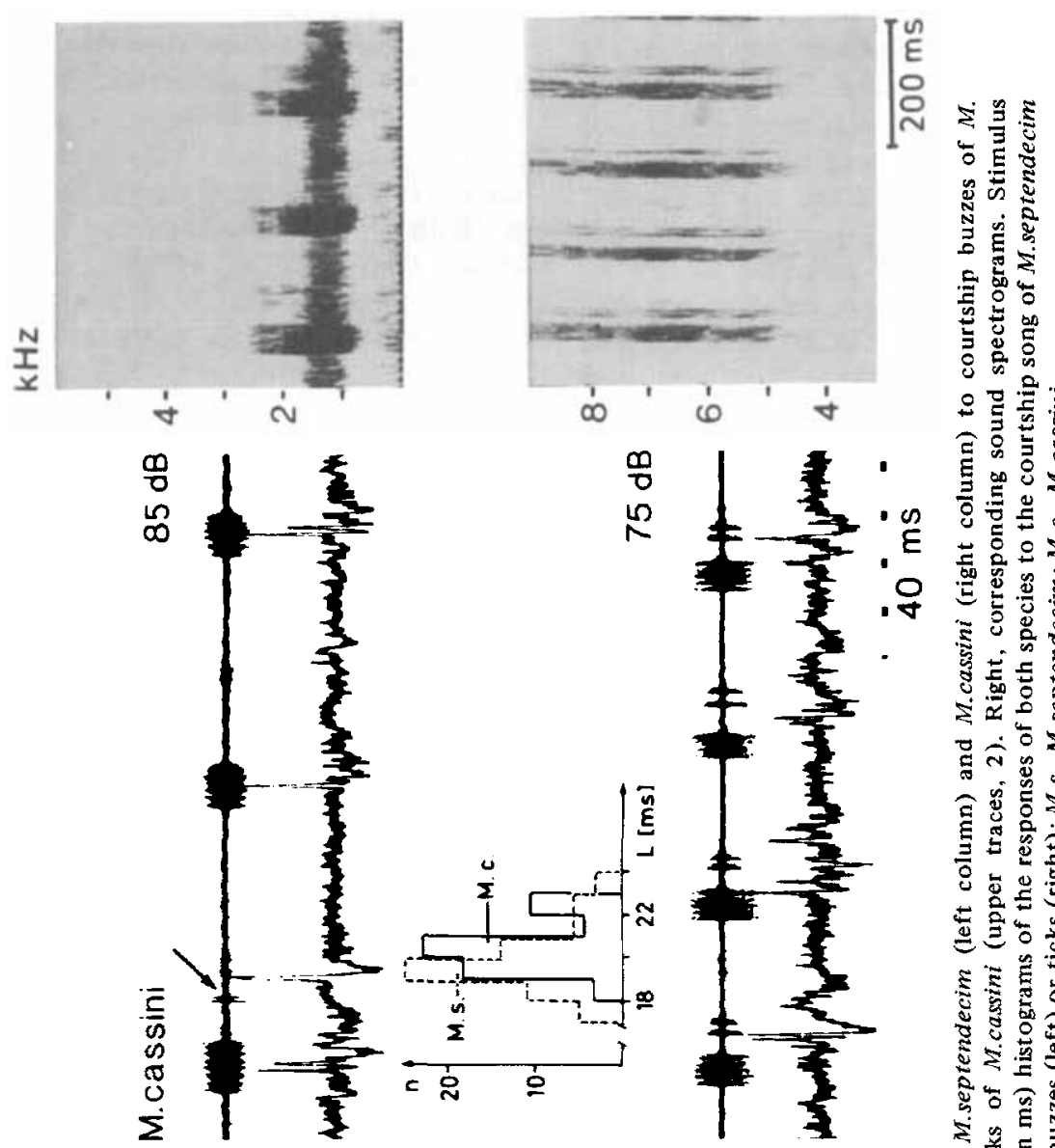

몰 욜

三

我 8

-

픙요
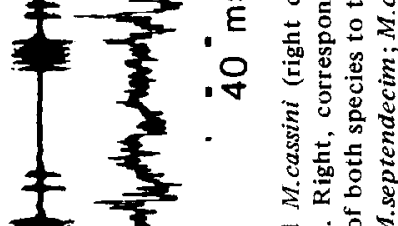

-

형ํㅇ

ลิ

寻要要

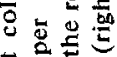

氖家范

₹

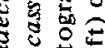

遗包

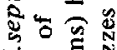

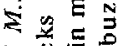

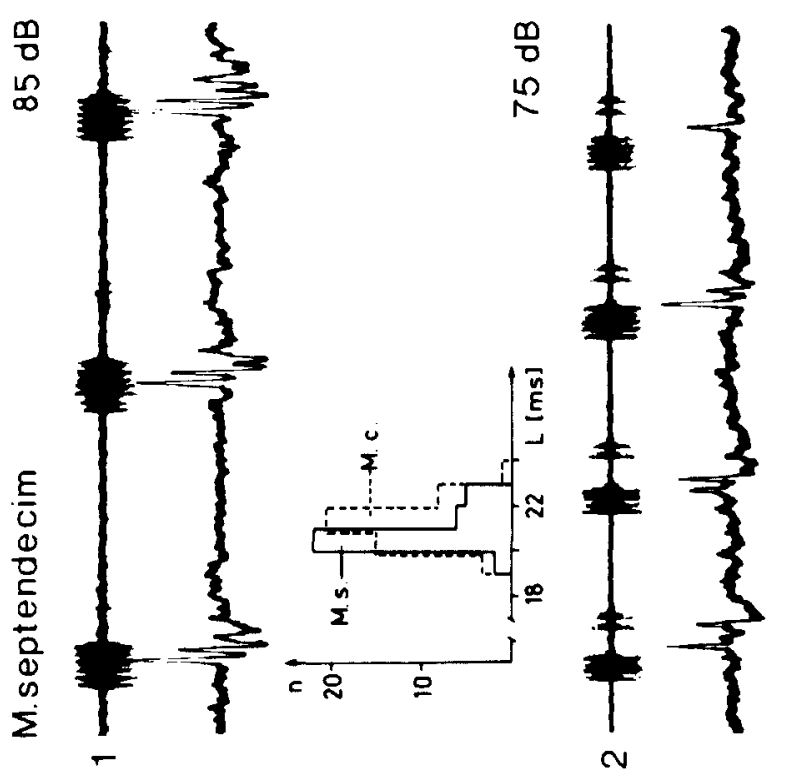

$\div$.

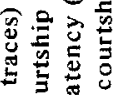

용 $=$

용

记

更

등

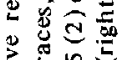

露的

ป

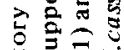

$\stackrel{2}{2}=$

$\exists \equiv$

小 总

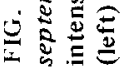


whereas M.cassini and M.septendecula calls elicited only weak responses, if any, in the M.septendecim nerve (Fig. 3, 2 and 3 left). This 'preference' for the conspecific song must be due to the tuning of the M.septendecim hearing organ to the low frequency components of its call (Fig. 3, sound spectrogram, top right; see also Simmons et al., 1971). Furthermore, the hearing organ is also sensitive to transients, as indicated in the weak response to M.septendecula ticks (Fig. 3, 3 left), even if their carrier frequency does not overlap that of the conspecific song.

In M.cassini and M.septendecula there seems to be no 'preference response' to the conspecific call (cf. Fig. 3, middle and right columns). In M.cassini and M.septendecula calls, the absence of a preference response is understandable, because both species emit calling songs with widely overlapping frequency spectra (Fig. 3, corresponding sound spectrograms). Nevertheless, there are also small differences in the auditory nerve responses between the two species, which indicate that the temporal structure of the conspecific song is more precisely copied (Fig. 3, cf. 2 middle with 3 right).
The M.cassini and M.septendecula responses to the calls of M.septendecim (Fig. 3, 1, middle and right) are not understood. They cannot result from a tuning to the low frequency part of the M.septendecim call, because in this range $(1-2 \mathrm{kHz})$ the $M$.cassini hearing organ is $50 \mathrm{~dB}$ less sensitive than that of M.septendecim (Simmons et al., 1971).

The courtship sounds of the three species of 17-year cicadas are composed of buzzes and/or ticks, differing in duration and rate (see Table 1). Fig. 4 shows parts of courtship songs of M.septendecim (1, upper traces) and $M$, cassini (2, upper traces) and corresponding sound spectrograms (right). There is no clear difference in the auditory nerve response of M.septendecim (Fig. 4, 1 and 2, left column, lower traces) or M.cassini (Fig. 4, 1 and 2, right column, lower traces) to conspecific and allospecific courtship sounds. The 'stronger' response of M.septendecim to the conspecific song is partly due to a $10 \mathrm{~dB}$ higher in tensity of the stimulus. Within the M.cassini courtship song (Fig. 4, 2, left column) the second tick within a double tick (Table 1) elicited no response in the M.septendecim ear, whereas the M.cassini ear (Fig. 4, 2, right column)
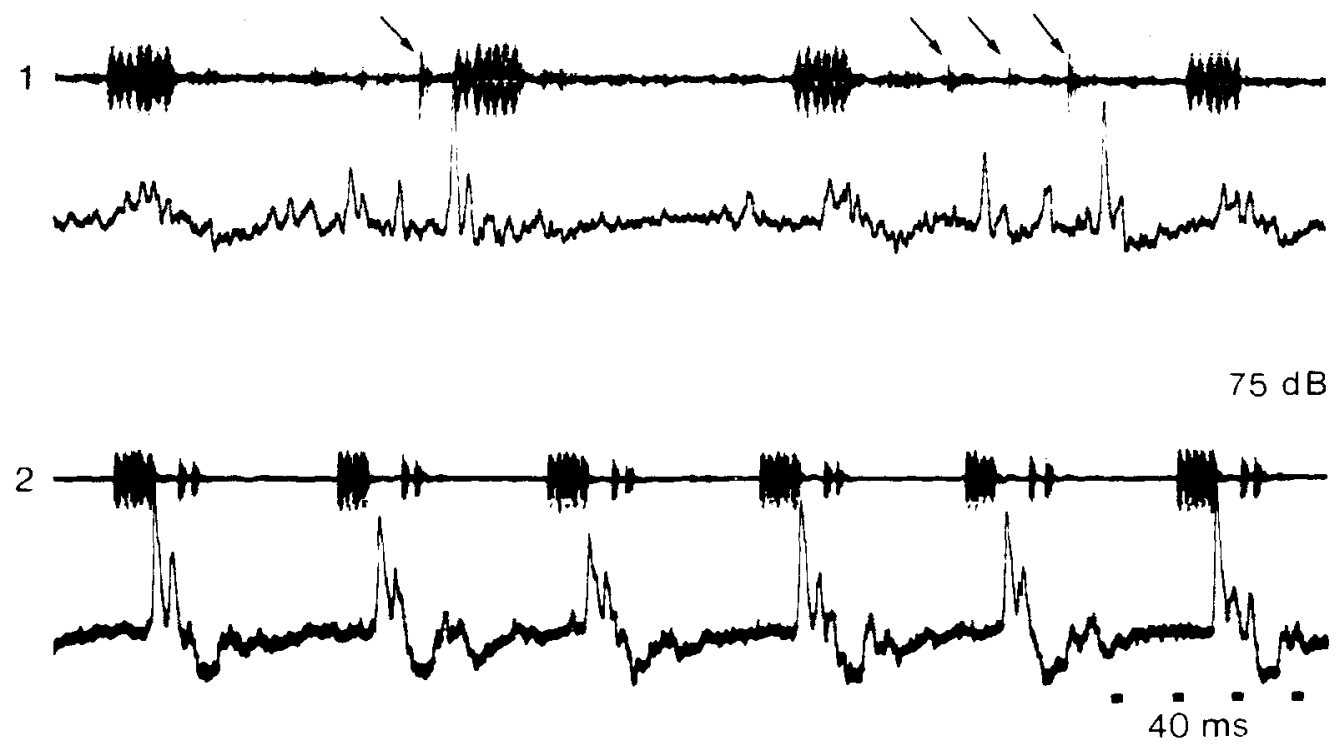

FIG. 5. A uditory nerve responses of O.rimosa (lower traces in 1 and 2) to M.septendecim (1) and $M$. cassini (2) courtship songs (upper traces in 1 and 2). Arrows point to sharp transients which originate from wing flipping, and which differ from the buzzes of M. septendecim in sound frequency content. Stimulus intensities $75 \mathrm{~dB}$ SPL. 
frequently copies the second tick too. The arrow in Fig. 4 (1, right column) points to a sharp transient which was on the stimulus tape but did not belong to the M. septendecim courtship sound. The strong response of $M$. cassini is again understandable, because such a transient contains sound frequencies overlapping those of the M.cassini songs.

There is no significant difference in the latency of the auditory nerve responses in the two species when stimulated with conspecific and allospecific courtship ticks, as shown by the histograms in Fig. 4. In M.septendecim the mean latency to conspecific sounds was $20.4 \mathrm{SD} \pm 0.8 \mathrm{~ms}$, and to allospecific sounds was $20.7 \pm 0.8 \mathrm{~ms}$. In $M$.cassini the values were $19.7 \pm 2.8 \mathrm{~ms}$ (conspecific) and $18.7 \pm 3.7 \mathrm{~ms}$ (allospecific). Such a result would be expected if the latency is mainly determined by the rise time of the sound.

Okanagana rimosa also emphasizes the importance of the sound frequency in its auditory nerve response. When stimulated with the courtship sounds of M.septendecim (Fig. 5, 1, upper trace) and of M.cassini (Fig. 5, 2 , upper trace) auditory receptors are excited. However, the compound response is considerably stronger to M.cassini courtship ticks (Fig. 5, 2, lower trace), the sound spectrum of which overlaps that of the O.rimosa calling and courtship songs (Table 1). The much weaker response to M.septendecim courtship sounds (Fig. 5, 1, lower trace) can again be explained by the lack of sound frequency

\section{O. rimosa}

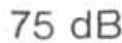

1

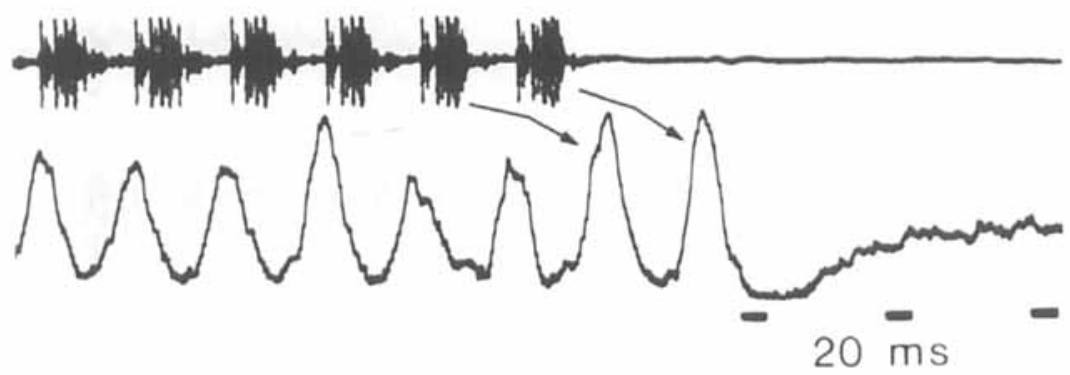

2

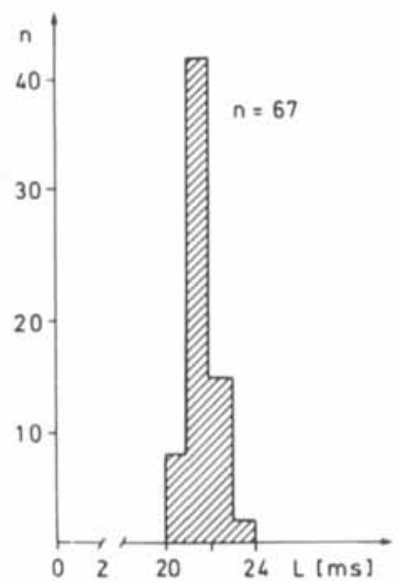

3

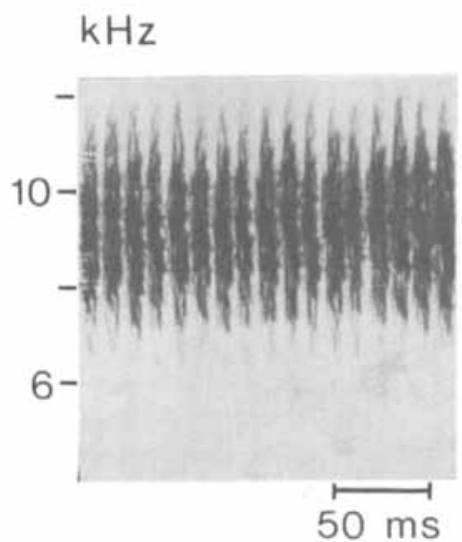

FIG. 6. 1. Auditory nerve responses (lower trace) of an O.rimosa female to six consecutive double pulses (combined close alternations of both tymbais) seen in the upper trace. Conspecific calling song is presented at $75 \mathrm{~dB}$ SPL. Arrows show the relationship of the compound auditory nerve potentials to corresponding double pulses. 2. Latency histogram $(n=67=$ no. of double pulses $)$ of the auditory compound action potentials (shown in 1). 3. Sound spectrogram of a part of the conspecific calling song with 17 double sound pulses; frequency range, $7-11 \mathrm{kHz}$. 
overlap between the two species. However, as soon as short transients with broad frequency bands are used as stimuli (arrows in Fig. 5, 1) the response is strongly increased and resembles that shown in Fig. 5, 2.

Temporal structure of the song and auditory nerve response

As already shown in Figs. 2-5, the compound auditory nerve response 'copies' the rhythm of buzzes and ticks, if those are presented within the appropriate frequency range. In all four species each single tymbal muscle contraction produces a sound pulse (Table 1) composed of a short train of sound bursts. The number of bursts is determined by the number of tymbal ribs being activated (Moore \& Sawyer, 1966; Moore \& Kausch, 1975). The individual sound bursts, each resulting from a single tymbal rib in-movement, are not copied in the summed auditory nerve activity, although there is an indication in some recordings that single auditory receptors or groups of receptors may even follow the rate of individual rib in-movements. However, the rate of sound pulses, each resulting from a tymbal action (i.e. single tymbal muscle

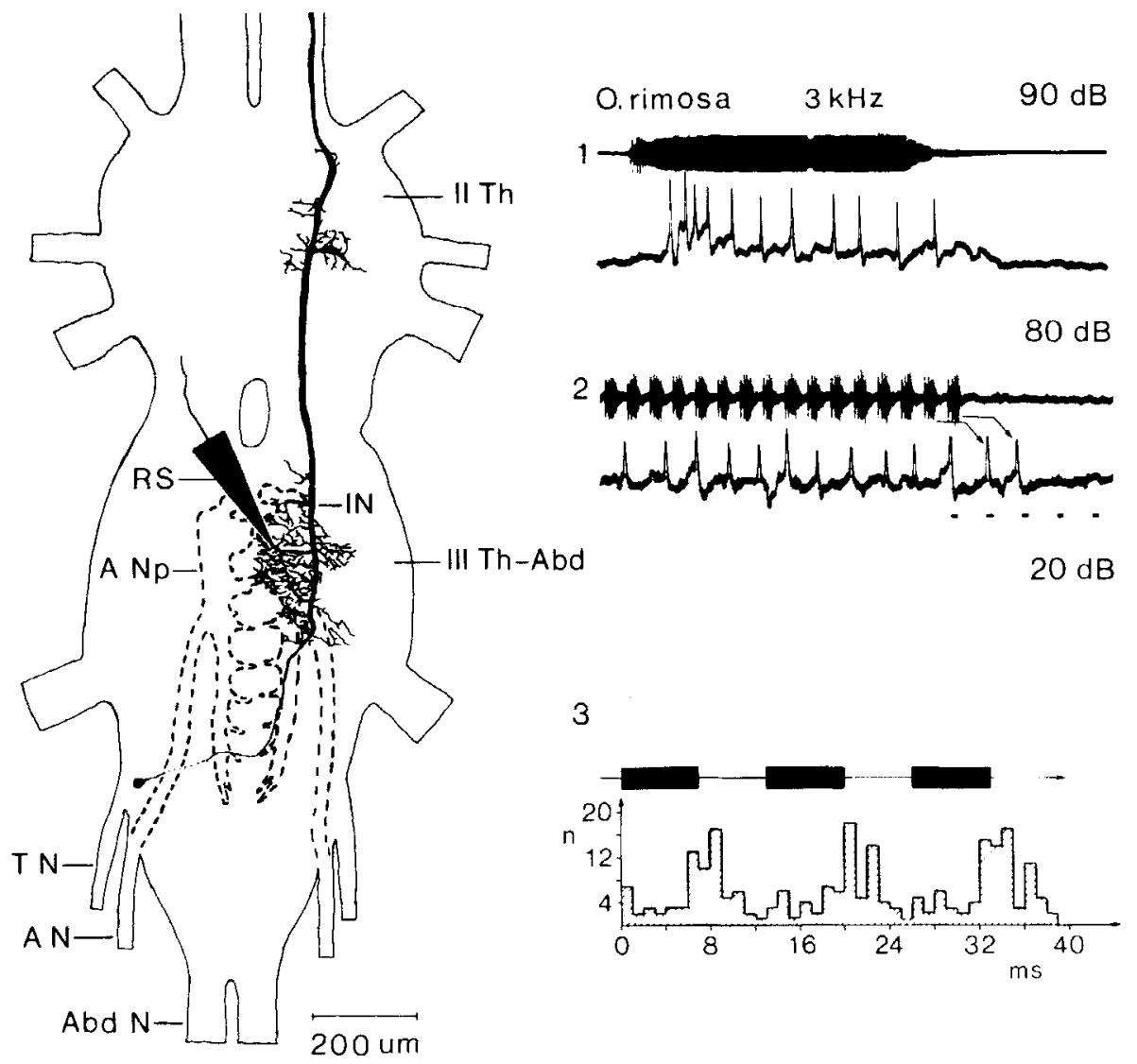

FlG. 7. Sketch of the mesothoracic (II Th) and the metathoracic-abdominal ganglionic complex (III Th-Abd) of female O.rimosa showing the auditory neuropiles (dashed lines, ANp) of both sides and an ascending interneurone ( $\mathrm{IN}$; from a camera lucida drawing) with arborizations in the meso- and metathoracic ganglia; RS, microelectrode recording site in a brancl which runs medially; other details as in Fig. 1. Right, intracellularly recorded responses to a $3-\mathrm{kHz}$ tone pulse at $90 \mathrm{~dB} \mathrm{SPL}$ (1), and to the conspecific calling song presented at $80 \mathrm{dBSPL}(2)$; arrows show the relationship of interneuronal spikes to corresponding sound pulses. 3, upper, three consecutive sound pulses (double pulses, schematized) of O.rimosa calling song drawn to correct time scale; 3 , lower, occurrences (n) of spikes per unit time relative to the onset of the previous three sound pulses within a continuous O.rimosa calling song. The neurone is modulated by the sound pattern. 
contraction) is copied by the summed auditory nerve response, as shown in Fig. $6(1$, lower trace). Each pulse gives rise to one compound action potential. The latencies vary between 20 and $23 \mathrm{~ms}$ in the case of O.rimosa (Fig. 6, 2: mean $21.2 \mathrm{SD} \pm 0.6 \mathrm{~ms})$. Furthermore, a rather stable phase relationship exists between sound pulse and the corresponding compound action potential. Artificial and short sound pulses in the best frequency range of the species were followed up to rates of $200 / \mathrm{s}$ which cover the natural range.

\section{Intracellular recording from an identified interneurone}

From the metathoracic ganglion intracellular recordings were made from interneurones responding to acoustic stimuli. Two recordings were obtained from $M$.septendecim, four from M.cassini, and six from O.rimosa. However, an interneuron (O.rimosa female) was stained in only one case and its structure was not completely revealed. The characterization, therefore, is mainly based on a physiological comparison of interneuronal responses studied in two Magicicada and one Okanagana species.

Morphological features. One successful intracellular staining was obtained in a female O.rimosa (Fig. 7, left). In this case the micropipette filled with a $30 \%$ cobalt nitrate solution penetrated one of the larger branches running toward the midline within the metathoracic ganglion (RS in Fig. 7). The interneurone has a cell body in the abdominal part of the ganglionic complex which is situated contralateral to the course of the ascending axon. A zone of arborization with medially and laterally oriented branches is limited to the metathoracic part of the ganglionic complex, and overlaps the anterior region of the sensory neuropile formed by elements of the auditory nerve (dashed line, Fig. 7; Wohlers et al, 1979). The axon, with a maximum diameter of $20 \mu \mathrm{m}$, runs forward to the meso- and prothoracic ganglia, and probably further. Within the mesothoracic ganglion the interneurone branches medially and laterally to regions of dorsal (motor?) neuropile.

Physiological features. The morphologically
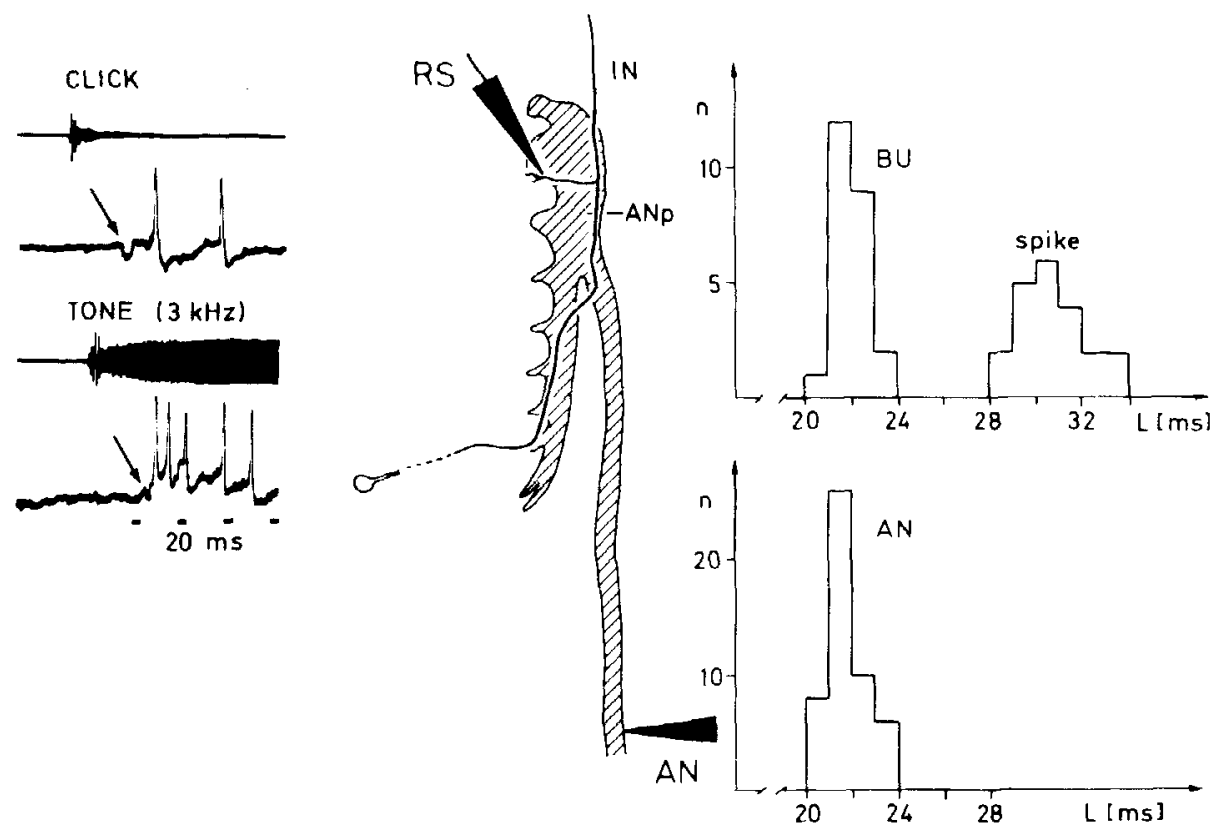

FIG. 8. Left, interne urone responses of O.rimosa female (same neurone as in Fig. 7) to click and tone. Arrows point to bumps. Centre, schematic drawing of one auditory neusopile (ANp) and of a part of the ascending interneurone (IN) shown in detail in Fig. 7; RS, recording site. Right, latency histograms of the responses in the auditory nerve close to its entrance in to the ganglionic complex (lower graph, $A N$ ), and of the responses in the interneurone (upper graph) separated for bumps (BU) and spikes (spike). 
identified interneurone of O.rimosa female responded to clicks, tones (Fig. 7, 1) and to conspecific calling and courtship songs (Fig. $7,2)$. Other songs could not be tested, because intracellular recordings with cobalt-electrodes did not usually last longer than $15 \mathrm{~min}$ (see Wohlers \& Huber, 1978). The spike response to the conspecific calling and courtship songs was frequently phase-locked to sound pulses originating from double tymbal actions (Fig. 7,3 ), though a single sound pulse did not always evoke a spike in the interneurone. Nevertheless, it is justifiable to conclude that the temporal pattern of pulses in the song, perfectly copied by the auditory nerve response (see Fig. 6, 1), also modulates the spike discharge in this ascending auditory interneurone.

As seen from intracellular responses to clicks and tones (Fig. 8, left), and natural songs (not shown in the figure) the spike train evoked in the interneurone is preceded by a bump of small amplitude and opposite polarity (arrows). We interpret this bump to be the reflection of an arriving afferent volley at the region of the microelectrode, an interpretation supported by latency measurements. Latencies for auditory nerve responses, recorded near the entrance to the ganglion and $0.6 \mathrm{~mm}$ away from the intracellular recording site (AN in Fig. 8) cover $20-23 \mathrm{~ms}$ (mean $21.3 \mathrm{SD} \pm 0.8$ ms). At comparable sound intensities (80-90 $\mathrm{dB}$ SPL) these latencies are very similar to those of the bumps seen at the interneurone recording site (RS in Fig. 8: range of latencies 20-23 ms; mean $21.5 \pm 0.7 \mathrm{~ms}$ ). Therefore, the possibility of direct transmission from auditory afferents to the interneurone cannot be excluded. In the preparation shown in Figs. 7 and 8 , spike latencies were several $\mathrm{ms}$ longer, indicating that the electrode was closer to the synaptic region than to the spike-generating
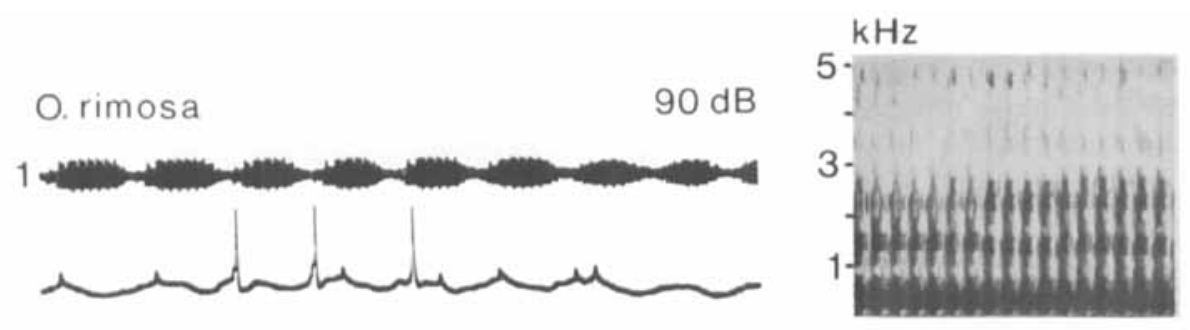

RRRR....
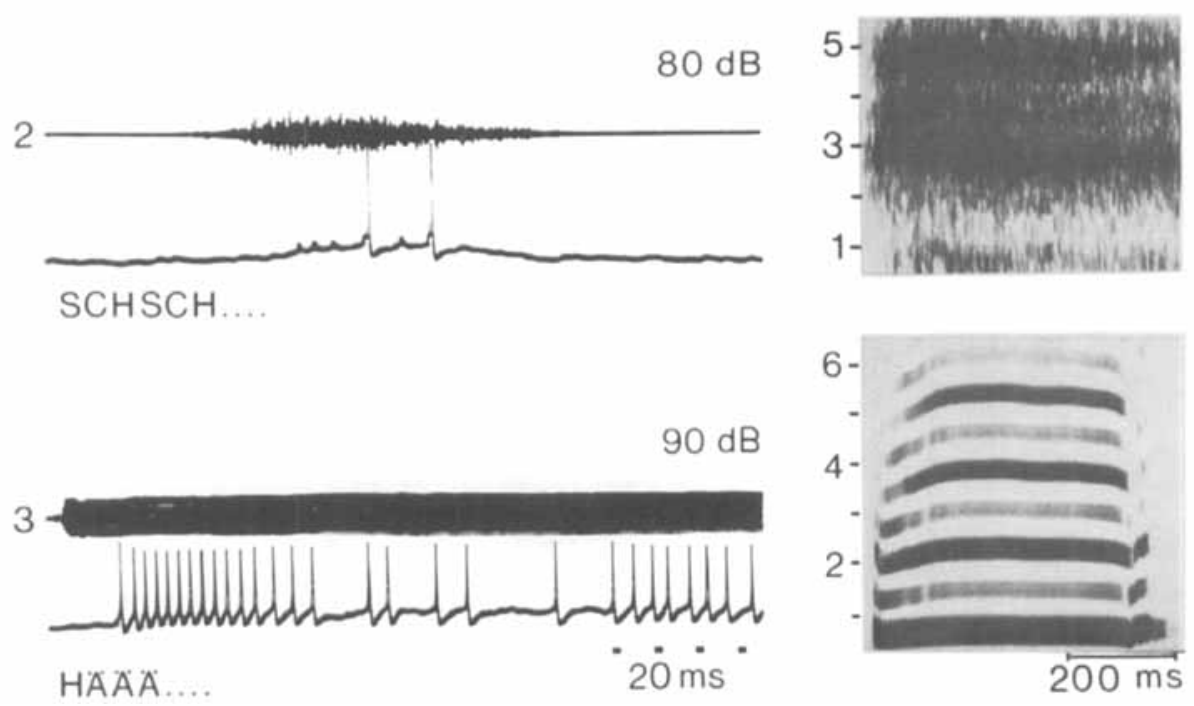

FIG, 9. Left, intracellularly recorded interneurone responses of an $O$.rimosa female (lower traces in $1-3$ ) to three types of sounds produced by human mouth (upper traces in 1-3) presented at 80 and $90 \mathrm{~dB}$ SPL. Right, corresponding sound spectrograms. 
zone. The close neighbourhood to the synaptic input region is also indicated by the strong sub-threshold activity of the interneurone.

Interneuronal responses to artificial sounds. Okanagana rimosa, and also 17-year cicadas, live in habitats where noises created by the wind, bird songs, sounds of other insect species, etc., are frequently heard. Birds in particular are known to hunt for cicadas. For the prey it would certainly be advantageous to extend the auditory range into the frequency bands used by possible predators. Fig. 9 shows responses of an interneurone in an O.rimosa female to artificial sounds produced by the human voice which were rough imitations of noises heard in the habitat of O.rimosa. None of the noises covered the best frequency range (Table 1) but parts of the sound spectra overlapped with those of O.rimosa songs. 'RRRR...' sounds, characterized by a sequence of 'pulses' repeated at a rate of approximately $30 \mathrm{~Hz}$, elicited rhythmical fluctuations of the membrane potential, EPSPs and spikes, the latter being phaselocked to the pulses (Fig. 9, 1). 'SCHSCH ...' noises depolarized the cell, EPSPs were generated and sometimes led to a spike (Fig. $9,2)$. The best spike response was achieved by the imitation of a bird cry (Fig. 9, 3).

Specificity of the interneurone response in sympatric species

One of the best examples for speciesspecificity within the auditory pathway of an

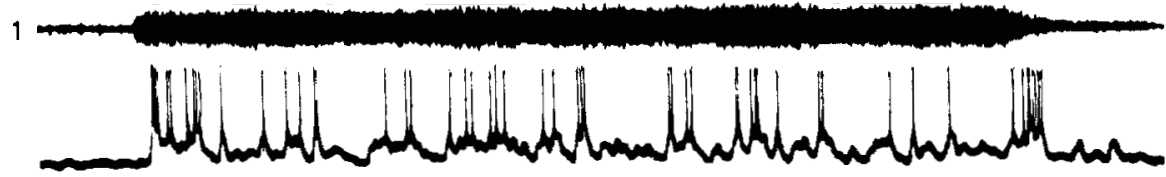

$80 \mathrm{~dB}$

2
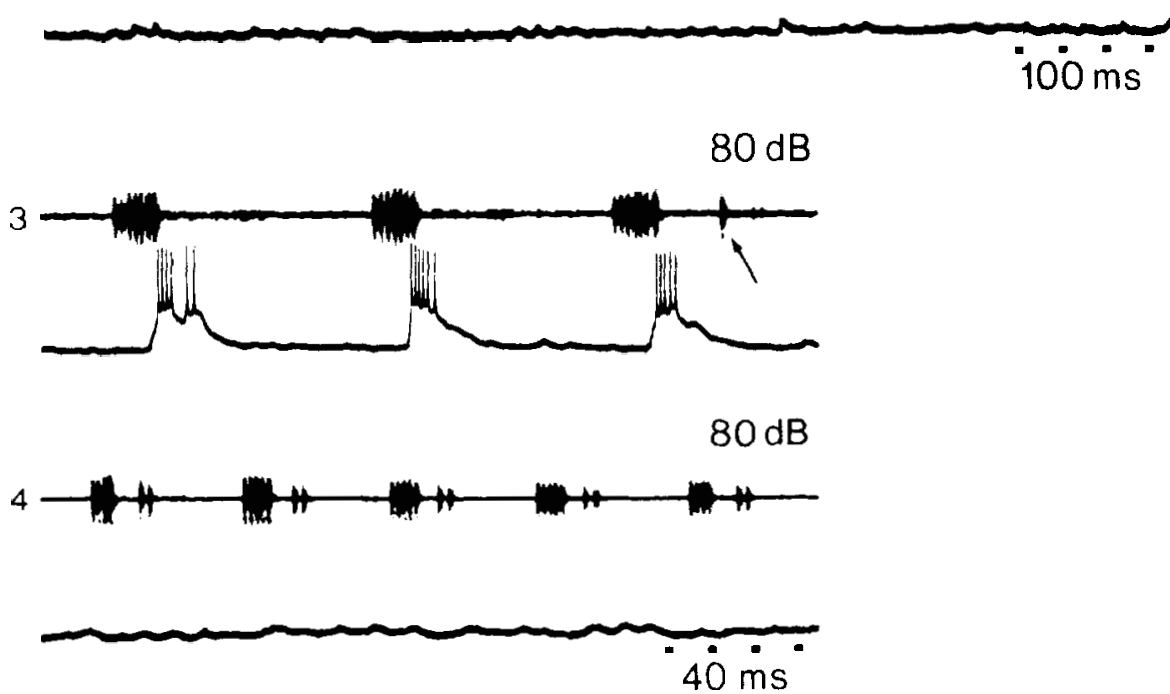

FIG. 10. Interneurone responses (recorded intracellularly) from a female M.septendecim (lower traces in $1-4)$ to conspecific calling and courtship songs (upper traces in 1 and 3 , respectively), and to allospecific M.cassini calling and courtship songs (upper traces in 2 and 4, respectively). Arrow in 3 points to single sound burst within a M.septendecim buzz which elicited no response. Stimulus intensities $80 \mathrm{~dB}$ SPL. 
insect is shown in the response of an interneurone from a M.septendecim female (Fig. 10). In the whole intensity range tested, conspecific calling and courtship songs caused a distinct depolarization and spike discharge (Fig. 10,1 and 3), whereas there was an entire lack of spike response to the songs of $M$. cassini (Fig. 10, 2 and 4). As far as the calling songs of the two species are concerned, the auditory nerve of M.septendecim acts as a filter, as already noted (Fig. 3, 1 and 2, left column), and there seems to be little input to the ganglion generated by the M.cassini call. However, and as indicated in Fig. 4 (2, left column), the auditory nerve of M. septendecim exhibits compound action potentials even in response to M.cassini courtship ticks at comparable intensities; therefore, the interneurone should receive auditory input. The complete absence of spikes, and the reduced sub-threshold activity (Fig. 10,2 and 4) must result from an additional filter acting between the auditory nerve input and the spike output of the interneurone.

M.cassini interneuronal responses also point to species-specificity (Fig. 11). Again the strong response to the conspecific calling song is striking, and in particular the high degree to which the temporal pattern is copied by the neurone both in sub-threshold (synaptic) and spike activity (Fig. 11, 2). The call of $M$. septendecim, even when presented at $10 \mathrm{~dB}$ higher intensity, elicited only a small increase if any in the spontaneous firing rate (Fig. 11, 1). Less striking, but nevertheless clearly visible, is the difference in response to conspecific and allospecific courtship sounds (Fig. 11, 3 and 4). The conspecific courtship sound elicited more spikes (imp.) per tick (Fig. 11, histograms lower right), and the temporal structure of the song was copied in great detail (Fig. 11, 4). A comparison of the strength of response in terms of numbers of spikes per M.cassini courtship tick (duration $20 \mathrm{~ms}$ ) shows a statistically significant difference (Fig. 11, lower right, right histogram), with the mean response to M.cassini (conspecific song) at $4.4 \pm 0.5$ spikes (imp.)/ $20 \mathrm{~ms}$ and to M.septendecim (allospecific song) $2.9 \pm 0.6$ spikes (imp.) $/ 20 \mathrm{~ms}$. There is a strong response of the M.cassini interneurone to sharp transients (Fig. 11, 3, arrow) which contain a much broader frequency band than the M.septendecim courtship buzzes (Table 1 ).

As shown in Fig. 12 (1) the spontaneously active interneurone of an O.rimosa female appears to be unaffected in its firing rate by the call of M.septendecim (Fig. 12, 1: mean interspike interval for the spontaneous discharge $42.1 \mathrm{SD} \pm 15 \mathrm{~ms}$, for the discharge during the call $43.4 \mathrm{SD} \pm 21 \mathrm{~ms}$ ). However, when stimulated with the call of M.cassini (Fig. 12, 2) the interneurone increased its firing rate during the buzz-part. Within the preceding series of ticks (Table 1) a grouping of spikes is recognizable. Also, M. septendecula calls modulated the spontaneous firing rate (Fig. 12,3) and the neurone copied ticks and buzzes. Again, the complete absence of a response to the $M$.septendecim call, and the modulating effect of the $M$,cassini and $M$. septendecula calls upon the O.rimosa interneuronal discharge can be explained by the differences in sound frequency spectra (see Table 1) and the overlap with O.rimosa songs.

A similar difference in the sound frequency spectra (Fig. 4) is responsible for the observation that M.septendecim courtship buzzes elicited much weaker or even nil responses in the O.rimosa interneurone, whereas M.cassini courtship ticks greatly modulated and timed the neurone's spontaneous discharge (Fig. 12, 4 and 5). The difference in response strength is statistically significant (Fig. 12, histogram lower right; mean for the courtship buzz stimulus of $M$. septendecim $0.8 \mathrm{SD} \pm 0.7$ spikes (imp.)/tick $(n=57)$, and for the courtship tick of M.cassini $2.7 \pm 0.7$ spikes (imp.)/tick $(n=57))$. Sharper transients, indicated by arrows in the M.septendecim courtship song (Fig. 12, 4), with a much broader frequency band led to a stronger $O$.rimosa interneuronal response.

Species-specificity in the M.septendecim and M.cassini interneuronal responses to natural conspecific and allospecific calling and courtship song appears to be primarily based on the frequency tuning of the hearing organs to the characteristic bands of the species song. However, there must exist additional filter properties within central parts of the auditory pathway to account for the interneurone's specificity in the frequency domain. 


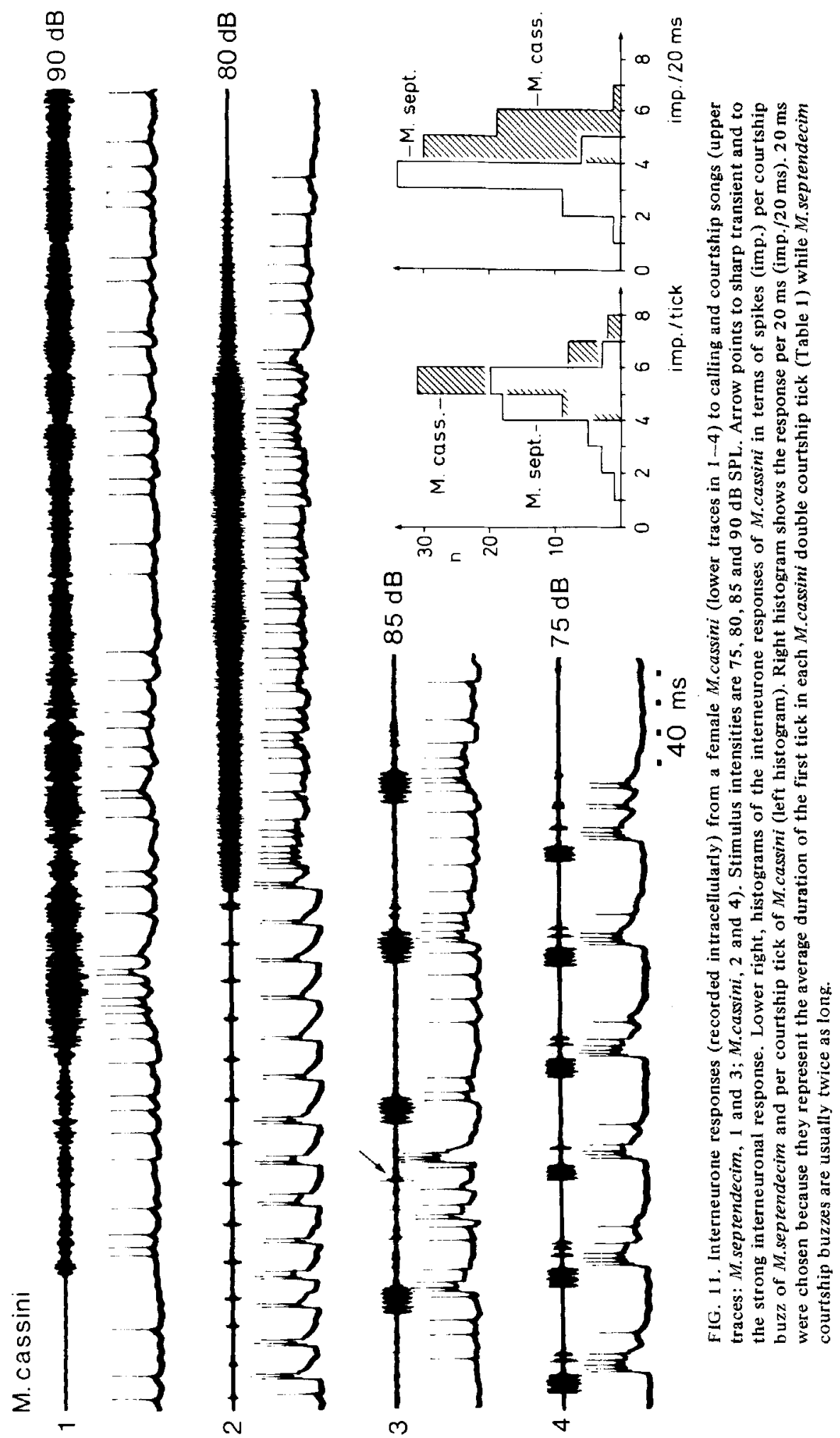


O. rimosa

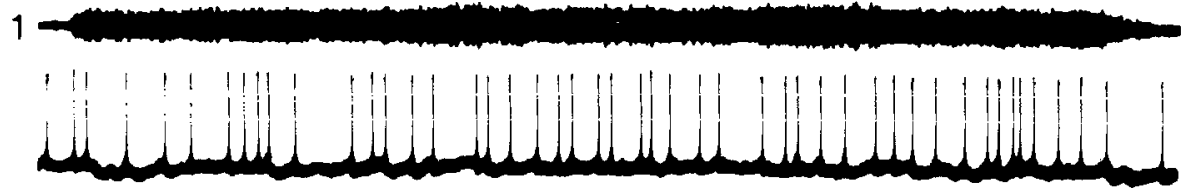

$80 \mathrm{~dB}$

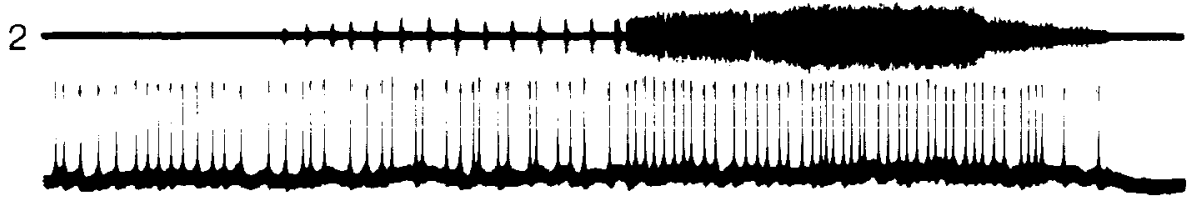

$80 \mathrm{~dB}$

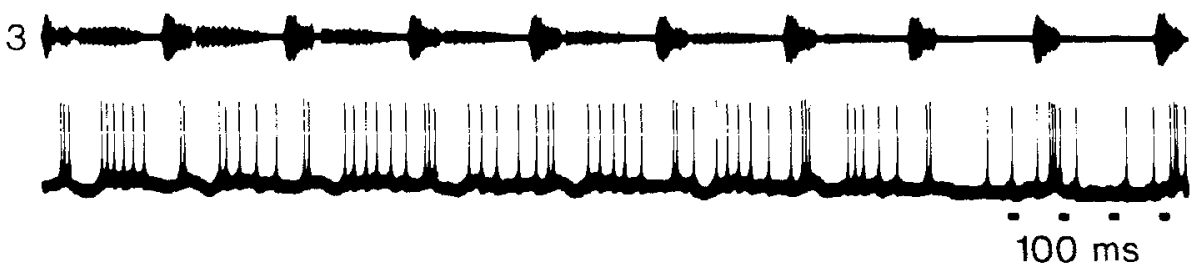

$85 \mathrm{~dB}$

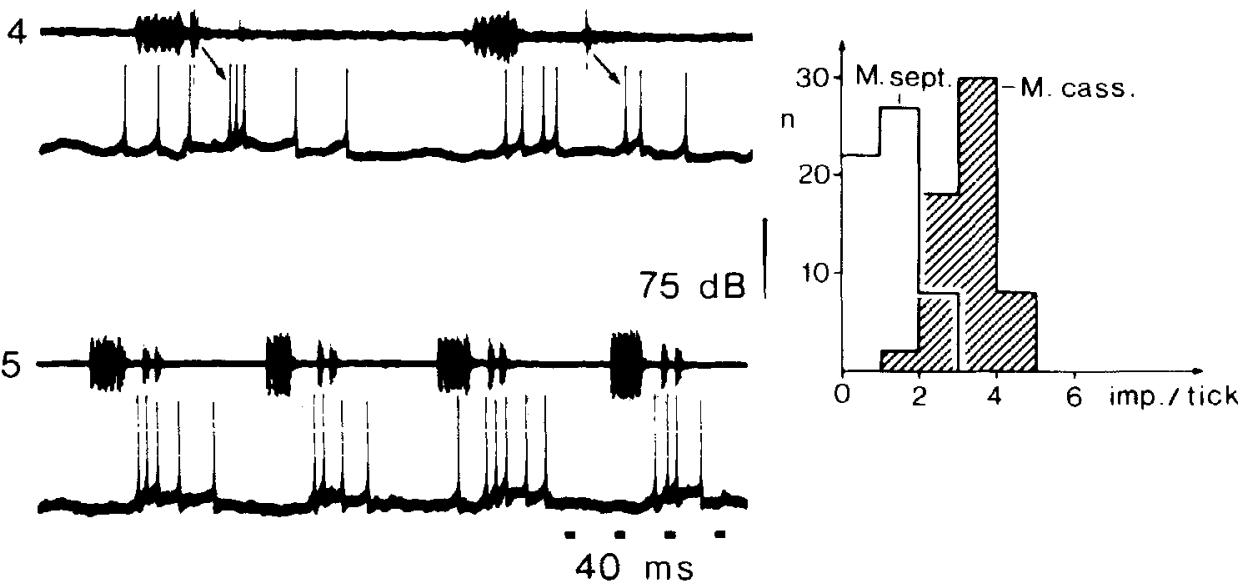

FIG. 12. Interneurone responses (lower traces in 1-5) of an O.rimosa female to calling (1-3) and courtship songs ( 4 and 5 ) of 17 -year cicadas presented at intensities of $75,80,85$ and $90 \mathrm{~dB}$ SPL. 1 and 4, M.septendecim songs; 2 and 5, M.cassini songs; 3, M.septendecula call (transition from the tick-buzz part to the tick). Arrows in 4 relate sharp transients in the M.septendecim courtship song (apparently sounds caused by wing flipping) to stronger in terneuronal responses. Lower right, histograms summarizing the spike responses, plotted as the number ( $n$ ) of spikes per tick (or short buzz) to M. septendecim and M.cassini courtship songs. 


\section{Discussion}

The investigation of sound communication behaviour in the field and within the laboratory, combined with studies of the structure and the function of sensory and neuronal elements composing the auditory pathway in insects, should eventually give some insight into the mechanisms governing sound reception, species discrimination, and species recognition. So far most of the work has been done on orthopterans; therefore it seems necessary to discuss present findings from a comparative standpoint.

\section{Behavioural aspects}

In gryllids, tettigonids and many cicadas, the males sing and the females respond phonotactically. In acridids, and some cicadas, both males and females stridulate and approach each other (Dumortier, 1963; Leston \& Pringle, 1963; Moore, 1973). Species-specific sound parameters have been described for all four groups of singing insects (see Alexander, 1960,1975 ); however, behavioural experiments designed to analyse intraspecific sound recognition are rare. For crickets this has been done by Regen (1913, 1923), Walker (1957), Murphey \& Zaretsky (1972), Zaretsky (1972), Ulagaraj \& Walker (1973, 1975), Popov et al. (1974), Hill (1974), Popov \& Shuvalow (1977), Hoy et al. (1977) and Moiseff et al. (1978); for acridids by Loher (1957), von Helversen (1972) and von Helversen, D. \& O. (1975). The studies of phonotaxis in gryllids and of sound responses in acridids have shown that the carrier frequency and the temporal patterns of the songs are the most significant behaviourally (see Elsner \& Huber, 1973; Elsner \& Popov, 1978). Therefore, the sensory and neuronal machinery which evolved in the context of processing sound signals must be suited to differentiate among these features. Unfortunately for cicadas, even for those species in which the songs are described in detail, very few quantitative behavioural studies have been performed (Alexander \& Moore, 1958). This is partly because of their long life cycles, short adult periods, daily activities, and difficulties with their food requirements. However, such studies are urgently needed, because they provide the platform for physiological investigations in sound communication.

\section{Auditory nerve and species demands}

In orthopterans, pitch discrimination is accomplished through the biophysical properties of the hearing organs which provide the basis for tuning of auditory receptors to different frequencies, paralleling the species' signals. Temporal features of the songs are copied in the spike discharge pattern of auditory sense cells (for crickets see Nocke (1972), Zhantiev \& Tshukanov (1972a,b), Hill (1974), Eibl \& Huber (1979) and Esch et al. (1980); for tettigonids see Zhantiev (1971), Rheinlaender (1975), Kalmring et al. (1978a) and Zhantiev \& Korsunovskaya (1978); for acridids see Michelsen (1966, 1971).

In cicadas less information is available and it is based only on auditory nerve recordings (see Introduction). M.septendecim songs are emitted in a frequency range which does not overlap those of the two other sympatric species, and its hearing organs appear sharply tuned to the intraspecific frequency bands (Simmons et al., 1971). This tuning may explain the powerful response in the auditory nerve to the conspecific call, and the failure to respond to allospecific songs, as shown in this paper. However, the parameter 'sound frequency' alone does not guarantee the acoustical separation of the three 17-year cicada species. For instance, the frequency spectra from the songs of $M$.cassini and $M$. septendecula overlap to a large degree, resulting in auditory nerve responses to songs of both species. But in these two species, interspecific separation may be improved through differences in the temporal organization of the song (Table 1) and in diel separation of singing periods (see Alexander \& Moore, $1958,1962)$. In addition, the courtship songs of all three species contain buzzes and ticks with sharp transients, and they are not separated at the level of the hearing organs (Figs. 4. and 5).

The structure and operation of the soundproducing apparatus enables cicadas to emit sound with sharp transients (Pringle, 1954; Moore \& Sawyer, 1966; Popov, 1975 ;Simmons \& Young, 1978). The hearing organs are 
adjusted to respond to such transients, as shown for Sri Lankan cicadas (Pringle, 1954), for a Brazilian cicada (Enger et al., 1969), and for North American species (this paper). The response seems to be best if the transients contain that frequency range to which the hearing organ is tuned, as strongly indicated in this paper.

All species studied here produce sounds only as each tymbal buckles inward, and are effectively silent during outward tymbal movement. In those species where the tymbals operate nearly continuously, repetition rates of $80-100 \mathrm{~Hz}$ are reached by each tymbal. Since the tymbals are driven alternately (see Hagiwara \& Watanabe, 1956; Moore \& Sawyer, 1966; Reid, 1971; Simmons \& Young, 1978) the total tymbal repetition rate is doubled and reaches values of up to $200 \mathrm{~Hz}$. Auditory sense cells are adjusted to such rates, and no adaptation is seen (Enger et al., 1969; and above). In all tymballing species, the tymbal is subdivided into ribs, and each rib causes a separate burst of sound. Such rib-bursts reach rates of $600-1000 \mathrm{~Hz}$ (Moore \& Sawyer, 1966) and together comprise the sound pulse from each tymbal. It is doubtful whether single auditory sense cells can resolve these rib-rates, although auditory nerve discharges from $O$.rimosa frequently show a rough outline of the substructure within a paired tymbal action (Fig. 6, 1).

\section{Auditory interneurones and species demands}

In orthopterans, the tuning of segmental and plurisegmental ascending and descending interneurones has been described together with how they copy the temporal structure of natural and artificial sounds (see Elsner \& Popov, 1978; and for recent data, Boyan, 1978, 1979b; Hoy, 1978; Kalmring et al., 1978a,b; Popov et al., 1978; Wohlers \& Huber, 1978; Stout \& Huber, in preparation).

In crickets, location of the sound source in space, which is partly due to the physical properties of the accessory structures of the hearing organs (Paton et al., 1977; Hill \& Boyan, 1977; Larsen \& Michelsen, 1978; Boyan, 1979a,b; Kleindienst et al., in preparation), is greatly improved by mutual inhibitory interactions via segmental interneurones (Wohlers \& Huber, 1978) and by the spread of this inhibitory influence to ascending auditory neurones (Wiese, personal communication). For cicadas, directional hearing has been shown in Cystosoma saundersii (Young \& Hill, 1977), but information at the interneuronal level is still lacking.

The processes underlying sound recognition begin at the level of the hearing organs and continue within the auditory pathway (see Elsner \& Popov, 1978; Huber, 1978). In orthopterans, ascending auditory neurones do not always exhibit a sharper tuning to sound frequencies than do primary auditory fibres (Popov, 1973; Kalmring, 1975; Rheinlaender, 1975; Rheinlaender et al., 1976, Stout \& Huber, in preparation). This means that species recognition in the sound frequency domain is mainly accomplished at the level of the sensory system.

For cicadas, quantitative information is still lacking, but there is good evidence, at least for M.septendecim and M.cassini that ascending interneurones cover approximately the same frequency range as the hearing organs. This is indicated by the strong response of the M.septendecim interneurone to conspecific calling and courtship songs, and the complete lack of response to M.cassini songs. However, there seem to be differences between cicada species, particularly as far as the courtship songs are concerned, where speciesspecificity is less pronounced. Finally, the interneurones recorded in O.rimosa females can be excited by tones outside the species song frequency range (Fig. 7), and they may thus serve other functions.

In the temporal domain, orthopterans possess ascending interneurones which copy song patterns in terms of syllables and chirps, without habituation (Stout \& Huber, 1972; Huber, 1977). But there exist others with different encoding properties (Popov et al., 1974; Kalmring, 1975; Rheinlaender, 1975). The interneurones recorded from M.septendecim and M.cassini cicadas seem to belong to the type of the non-habituating units which encode buzzes and ticks, the thythm elements of cicada songs. They can be considered as part of the sound recognizing system within the CNS.

There are field observations from Alexander \& Moore (1958) which support our finding of a preference in copying the temporal 
parameters of the conspecific calling songs of M.septendecim and M.cassini. In field behavioural analyses of tape-recorded sounds of M.cassini males, Alexander \& Moore found that hearing only the beginning of the buzz part of their calling song stimulated buzzing in the males, while hearing the whole buzz or a suddenly interrupted buzz stimulated ticking within about half a second. Hearing only the ticking part of the call commonly caused males to buzz. Furthermore, males of M.cassini also sang more often when hearing their calling songs, but not when hearing their courtship sounds. There was no increase in singing when hearing the calling songs of M.septendecim.

\section{Acknowledgments}

The authors are most grateful to the Max Planck Society and the University of Michigan for financing the research, and to the Museum of Zoology and the Division of Biological Sciences, The University of Michigan, Ann Arbor, for providing equipment and laboratory facilities. They are also grateful to Ms $\mathrm{H}$. Bamberg for her assistance with the photographic work.

\section{References}

Alexander, R.D. (1960) Sound communication in Orthoptera and Cicadidae. In: Animal Sounds and Communication (ed. by W. E. Lanyon and W. N. Tavolga), Vol. 7, pp. 38-92. American Institute of Biological Sciences, Washington, D.C.

Alexander, R.D. (1975) Natural selection and specialized chorusing behavior in acoustical insects. Insects, Science and Society, pp. 3577. Academic Press, New York.

Alexander, R.D. \& Moore, T.E. (1958) Studies on the acoustical behavior of seventeen-year cicadas (Homoptera: Cicadidae: Magicicada). Ohio Journal of Science, 58, 107-127.

Alexander, R.D. \& Moore, T.E. (1962) The evolutionary relationships of 17 -year and 13 -year cicadas, and three new species (Homoptera, Cicadidae, Magicicada). Miscellaneous Publications of the Museum of Zoology, Michigan, 121, 1-59.

Bacon, J.P. \& Altman, J.S. (1977) A silver in tensification method for cobalt filled neurones in wholemount preparations. Brain Research, 138 , $359-363$.
Boyan, G.S. (1978) Coding of directional information by a descending interneuron in the auditory system of the cricket. Naturwissenschaften, 65, 272.

Boyan, G.S. (1979a) Directional responses to sound in the central nervous system of the cricket Teleogryllus commodus (Orthoptera: Gryllidae). I. Ascending interneurones. Joumal of Comparative Physiology, 130, 137-150.

Boyan, G.S. (1979b) Directional responses to sound in the central nervous system of the cricket Teleogryllus commodus (Orthoptera: Gryllidae). II. A descending interneurone. Journal of Comparative Physiology, 130, 151-159.

Dumortier, B. (1963) The physical characteristics of sound emissions in Arthropoda. Acoustic Behaviour of Animals, pp. 347-373. Elsevier Publishing Company, London.

Dybas, H.S. \& Davis, D.D. (1962) A population census of seventeen-year periodical cicadas (Homoptera: Cicadidae: Magicicada). Ecology, 43, 432-444.

Eibl, E. \& Huber, F. (1979) Central projections of tibial sensory fibers within the three thoracic ganglia of crickets (Gryllus campestris L., Gryllus bimaculatus DeGeer). Zoomorphologie, 92, 1-17.

Elsner, N. \& Huber, F. (1973) Neurale Grundlagen artspezifischer Kommunikation bei Orthopteren. Fortschritte der Zoologie, 22, 1-48.

Elsner, N. \& Popov, A.V. (1978) Neuroethology of acoustic communication. Advances in Insect Physiology, 13, 299-335.

Enger, P.S., Aidley, D.J. \& Szabo, T. (1969) Sound reception in the Brazilian cicada, Fibicina rana Walk. Journal of Experimental Biology, 51, $339-345$.

Esch, H., Huber, F. \& Wohlers, D.W. (1980) Physiological and anatomical characterization of single sensory auditory units in crickets. In press.

Fielden, A.A. (1960) Transmission through the last abdominal ganglion of the dragonfly nymph, Anax imperator. Journal of Experimental Biology, $37,832-844$.

Hagiwara, S. \& Watanabe, A. (1956) Discharges in motoneurons of cicada. Journal of Cellular and Comparative Physiology, 47, $415-428$.

Heath, J.E. (1967) Temperature responses of the periodical '17-year' cicada, Magicicada cassini (Homoptera, Cicadidae). American Midland Naturalist, 77, 64-76.

Helversen, D. von (1972) Gesang des Männchens und Lautschema des Weibchens bei der Feldheuschrecke Chorthippus biguttulus (Orthoptera: Acrididae). Journal of Comparative Physiology, $81,381-422$.

Helversen, D. von \& Helversen, $O$. von (1975) Verhaltensgenetische Untersuchungen am akustischen Kommunikationssystem der Feldheuschrecken (Orthoptera: Acrididae). Journal of Comparative Physiology, 104, 273-323.

Hill, K.G. (1974) Carrier frequency as a factor in phonotactic behaviour of female crickets (Teleagryllus commodus). Joumal of Compara tive Physiology, 93, 7-18. 
Hill, K.G. \& Boyan, G.S. (1977) Sensitivity to frequency and direction of sound in the auditory system of crickets (Gryllidae). Journal of Comparative Physiology, 121, 79-97.

Hoy, R.R. (1978) Acoustic communication in crickets: a model system for the study of feature detection. Federation Proceedings, 37, 23162323.

Hoy, R.R., Hahn, J. \& Paul, R.C. (1977) Hybrid cricket auditory behavior: evidence for genetic coupling in animal communication. Science, 195 , $82-84$.

Huber, F. (1977) Lautäusserungen und Lauterkennen bei Insekten (Grillen). Rheinisch-Westfälische Akademie der Wissenschaften, Vortrag N 265, $15-66$.

Huber, F. (1978) Insektensprache. Erforschung der Arbeitsweise kleinerer Nervensysteme. Jahrbuch der Max Planck Gesellschaft, pp, 5 5-78.

Kalmring, K. (1975) The afferent auditory pathway in the ventral cord of Locusta migratoria (Acrididae). Journal of Comparative Physiology, 104, $103-141$.

Kalmring, K., Lewis, B. \& Eichendorf, A. (1978a) The physiological characteristics of the primary sensory neurons of the complex tibial organ of Decticus verrucivorus L. (Orthoptera, Tettigonioidae). Journal of Comparative Physiology, $127,109,121$.

Kalmring, K, Kühne, R. \& Moysich, F. (1978b) The coding of sound signals in the ventral-cord auditory system of the migratory locust, Locusta migratoria. Journal of Comparative Physiology, $128,213-226$.

Katsuki, Y. (1960) Neural mechanism of hearing in cats and insects. Electrical Activity of Single Cells (ed. by Y. Katsuki), pp. 53-75. Igakushoin, Hongo, Tokyo.

Katsuki, Y. \& Suga, N. (1960) Neural mechanism of hearing in insects. Joumal of Experimental Biology, 37, 279-290.

Larsen, O.N. \& Michelsen, A. (1978) Biophysics of the Ensiferan ear. III. The cricket eat as a four in put system. Journal of Comparative Physiology, $123,217-227$.

Leston, D. \& Pringle, J.W.S. (1963) Acoustic behaviour in Hemiptera. Acoustic Behaviour of Animals (ed. by R. G. Busnel), pp. 391-411. Elsevier Publishing Company, Amsterdam.

Loher, W. (1957) Unntersuchungen über den Aufbau und die Entstehung der Gesänge einiger Feld. heuschreckenarten und den Einfluss von Lautzeichen auf das akustische Verhalten. Zeitschrift für Vergleichenden Physiologie, 39, 313-356.

Michel, K. (1975) Das Tympanalorgan von Cicada orni L. (Cicadina, Homoptera). Zoomorphologie, 82, 63-78.

Michelsen, A. (1966) Pitch discrimination in the locust ear: observations on single sense cells. Joumal of Insect Physiology, 12,1119-1131.

Michelsen, A. (1971) The physiology of the locust ear. Zeitschrift für Vergleichenden Physiologie, $71,49-128$.

Moiseff, A., Pollack, G.S. \& Hoy, R.R. (1978)
Steering responses of flying crickets to sound and ultrasound: Mate attraction and predator avoidance. Proceedings of the National A cademy of Sciences of the United States of America, 75, $4052-4056$

Moore, T.E. (1973) Acoustical communication in insects. Introductory Entomology (ed. by V. Tipton). Brigham Young University Press, Syllabus: $307-323+$ Tape.

Moore,T.E.\& Alexander, R.D. (1956) The periodical cicada complex (Homoptera: Cicadidae). Proceedings of the 10th International Entoma logical Congress, Montreal 1956, 1, 349-355.

Moore, T.E. \& Kausch, W.J. (1975) 17-y ear cicadas (Magicicada septendecim L.). Publication of the University of Michigan Museum of Zoology, Movie, colour and sound, half hour.

Moore, T.E. \& Sawyer, R.T. (1966) The mechanism of cicada timbal action (Insecta: Homoptera: Cicadidae). American Zoologist, 5, 509.

Murphey, R.K. \& Zaretsky, M.D. (1972) Orientation to calling song by female crickets, Scapsipedus marginatus (Gryllidae). Joumal of Experimental Biology, 56, 335-352.

Nocke, H. (1972) Physiological aspects of sound communication in crickets (Gryllus campestris L.). Joumal of Comparative Physiology, 80, $141-162$

Paton, J.A., Capranica, R.R., Dragsten, P.R.S. \& Webb, W.W. (1977) Physical basis for auditory frequency analysis in field crickets (Gryllidae). Journal of Comparative Physiology, 119, 221 240.

Popov, A.V. (1973) Frequency selectivity of the reaction of auditory neurons in the 1 st thoracic ganglion of the cricket, Gryllus bimaculatus. Zhumal Evolyutsionnoi Biokhimii $i$ Fiziologii, 9, 265-277 | in Russian ].

Popov, A.V. (1975) The structure of tymbals and characteristic of sound signals of singing cicadas (Homoptera: Cicadidae). Revue d'Entomologie de I'URSS, 54, 258-290.

Popov, A.V., Markovich, A.M.\& Andjan, A.S. (1978) Auditory interneurons in the prothoracic ganglion of the cricket, Gryllus bimaculatus DeGeer. Journal of Comparative Physiology, 126, 183192.

Popov, A.V. \& Shuvalov, V.F. (1977) Phonotactic behavior of crickets. Journat of Comparative Physiology, 119, 111-126.

Popov, A.V., Shuvalov, V.F., Svetlogorskaya, I.D. \& Markovich, A.M. (1974) Acoustic behavior and auditory system in Insects. Mechanoreception Symposium (ed. by J. Schwartzkopff), pp. 281306. Adhandlungen der Rheinisch-Westfälischen Akademie der Wissenschaften, Band 53.

Pringle, J.W.S. (1954) A physiological analysis of cicada song. Journal of Experimental Biology, $31,525-560$.

Pringle, J.W.S. (1957) The structure and evolution of the organs of sound-production in cicadas. Proceedings of the Linnean Society of London, Session 167, 144-159.

Regen, J. (1913) Über die Anlockung des Weibchens 
von Gryllus campestris $\mathrm{L}$, durch telefonisch übertragene Stridulationslaute des Männchens. Pflügers Archiv für die Gesamte Phy siologie, 155, $193-200$.

Regen, J. (1923) Über die Orientierung des Weibchens von Lyogryllus campestris $L$. nach dem Stridulationsschall des Männchens. Ein Beitrag zur Physiologie des tympanalen Sinnesorgans. Sitzungsberichte Akademie der Wissenschaften Wien, Math.-naturw. Klasse, Abtl. III, 132 , $81-88$.

Reid, K.H. (1971) Periodical cicada: mechanism of sound production. Science, 172, 949-957.

Rheinlaender, 1. (1975) Transmission of acoustic information at three neuronal levels in the auditory system of Decticus verrucivorus (Tettigoniidae, Orthoptera). Journal of Comparative Physiology, 97, 1-53.

Rheinlaender, J., Kalmring, K., Popov, A.V. \& Rehbein, H.G. (1976) Brain projections and information processing of biologically significant sounds by two large ventral-cord neurons of Gryllus bimaculatus DeGeer (Orthoptera, Gryllidae). Journal of Comparative Physiology, $110,251-269$.

Simmons, J.A., Wever, E.G. \& Palka, J.M. (1971) Periodical cicada: sound production and hearing. Science, 171, 212-213.

Simmons, P. \& Young, D, (1978) The tymbal mechanism and song patterns of the bladder cicada, Cystosoma saundersii. Journal of Experimental Biology, 76, 27-45.

Stout, J.F. \& Huber, F. (1972) Responses of central auditory neurons of female crickets (Gryllus campestris L.) to the calling song of the male. Zeitschrift für Vergleichende Physiologie, 76, $302-313$.

Stout, J.F. \& Huber, F. (1980) Encoding by central auditory neurons of behaviorally significant features of the calling song in female crickets (Gryllus campestris L.). In preparation.

Ulagaraj, S.M. \& Walker, T.J. (1973) Phonotaxis of crickets in flight: attraction of male and female crickets to male calling songs. Science, 182, $1278-1279$.

Ulagaraj, S.M. \& Walker, T.J. (1975) Response of flying mole crickets to three parameters of synthetic songs broadcast outdoors. Nature, 253, $530-532$

Vasvary, L.M. (1966) Musculature and nervous system of the thorax, of the sound mechanism, and of typical pregenital abdominal segment of the male of the annual cicada, Tibicen chloro- mera (Walker) (Homoptera: Cicadidae). New York Entomological Society, 74, 2-55.

Vogel, R. (1923) Über ein tympanales Sinnesorgan, das mutmassliche Hörorgan der Singzikaden. Zeitschrift für Anatomie und Entwicklungsgeschichte, 67, 190-231.

Walker, T.J. (1957) Specificity in the response of female tree crickets (Orthoptera: Gryllidae: Oecanthinae) to calling songs of males. Annals of the Entomological Society of America, 50 , $626-636$.

Wohlers, D.W. \& Huber, F. (1978) Intracellular recording and staining of cricket auditory interneurons (Gryllus campestris L., Gryllus bimacu. latus DeGeer). Joumal of Comparative Physiology, 127, 11-28.

Wohlers, D.W., Williams, J.L.D., Huber, F.\& Moore, T.E. (1979) Central projections of fibers in the auditory and tensor nerves of cicadas (Homoptera: Cicadidae). Cell and Tissue Research, in press.

Young, D. (1975) Chordotonal organs associated with the sound producing apparatus of cicadas (Insecta: Homoptera), Zeitschrift für Morphologie der Tiere, 81, 111-135.

Young, D. \& Hill, K.G. (1977) Structure and function of the auditory system of the cicada, Cystosoma saundersii. Journal of Comparative Physiology, $117,23-45$.

Zaretsky, M.D. (1972) Specificity of the calling song and short term changes in the phonotactic response by female crickets, Scapsipedus marginatus (Gryllidae). Joumal of Comparative Physiology, 79, 153-172.

Zhantiev, R.D. (1971) Frequency characteristics of tympanal organs in grasshoppers (Orthoptera, Tettigoniidae). Zoologichesky Zhyrnal, 50, 507514.

Zhantiev, R.D. \& Korsunovskaya O.S. (1978) Morphofunctional organization of tympanal organs in Tettigonia cantans (Orthoptera, Tettigoniidae). Zoologichesky Zhymal, 57, 10121016.

Zhantiev, R.D. \& Tshukanov, V.S. (1972a) Frequency characteristics of tympanal organs of the cricket Gryllus bimaculatus DeGeer (Orthoptera, Gryllidae). Vestnik MGU Section Biology, 2, 3-8.

Zhantiev, R.D. \& Tshukanov, V.S. (1972b) Reaction of the auditory system of Gryllus bimaculatus to intraspecific sound signals. Zoologichesky Zhymal, 51, 983-993.

Accepted 2 October 1979 